\title{
Deep Incarnation: Why Evolutionary Continuity Matters in Christology
}

Gregersen, Niels Henrik

Published in:

Toronto Theological Journal

Publication date:

2010

Document version

Early version, also known as pre-print

Citation for published version (APA):

Gregersen, N. H. (2010). Deep Incarnation: Why Evolutionary Continuity Matters in Christology. Toronto Theological Journal, 26(2), 173-188. 


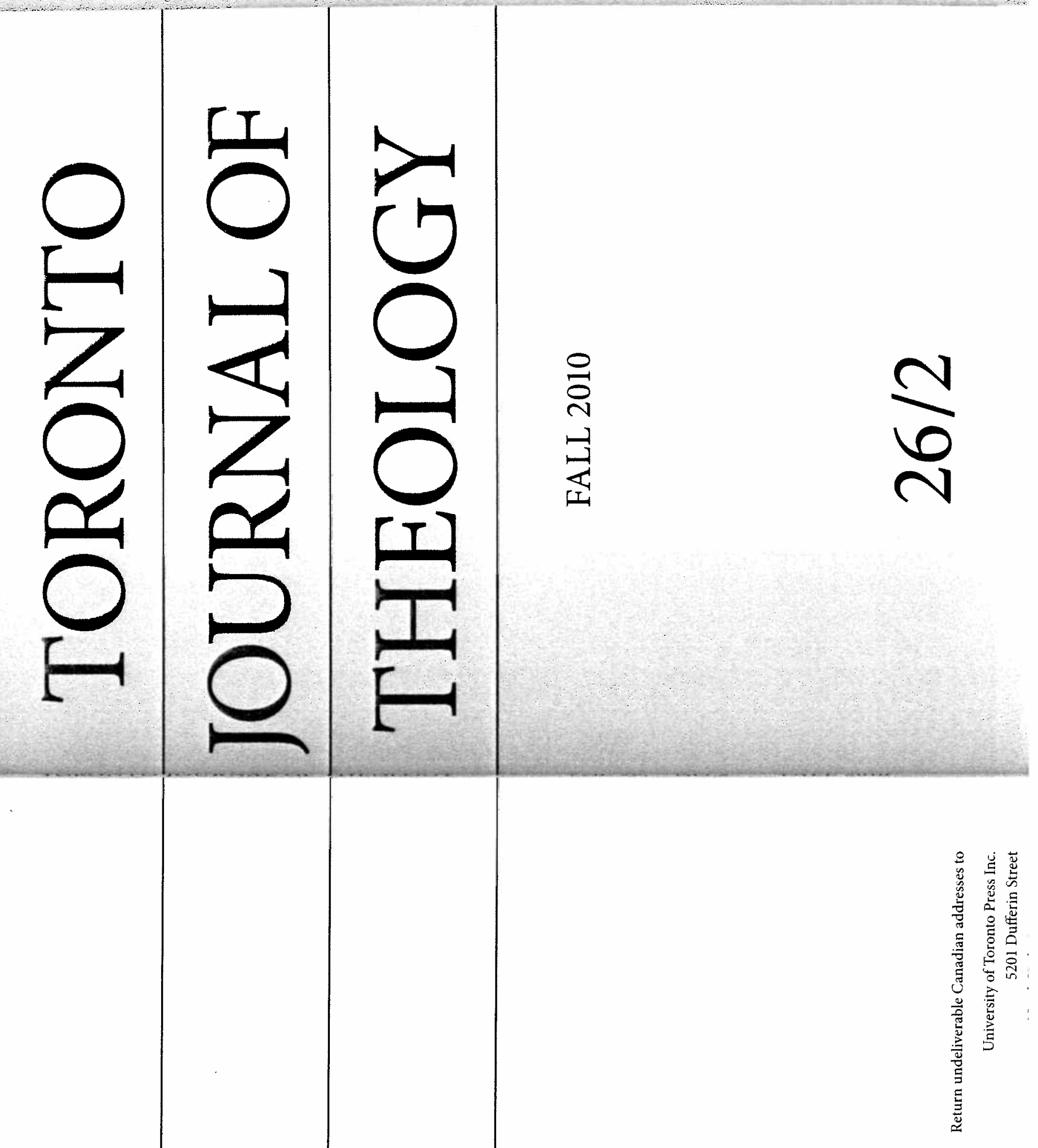




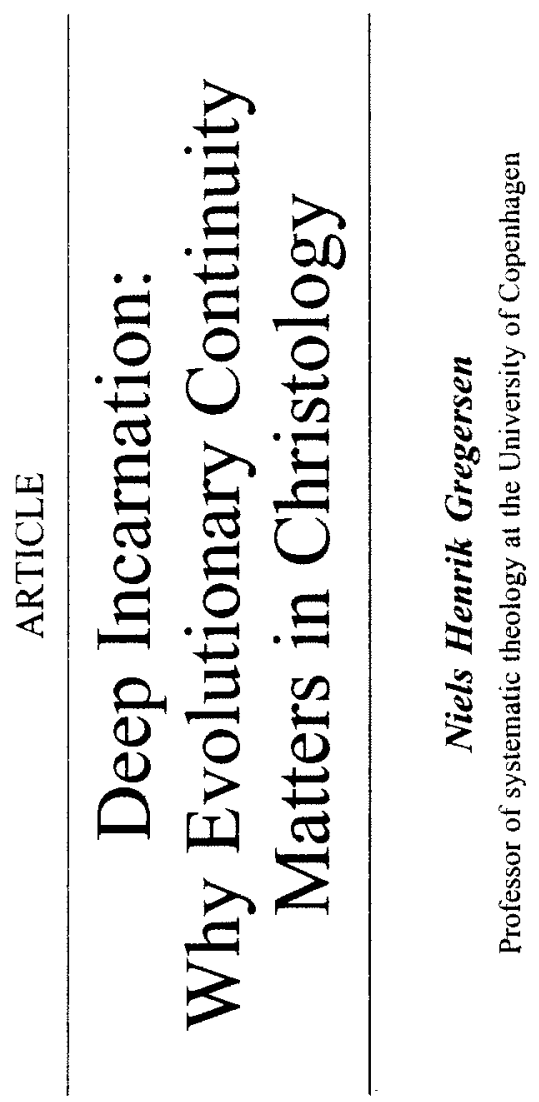

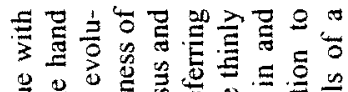

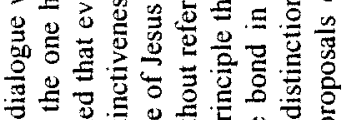

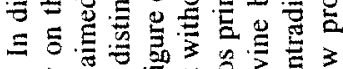

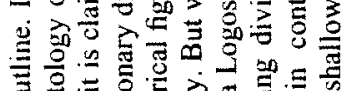

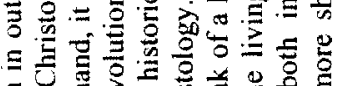

音

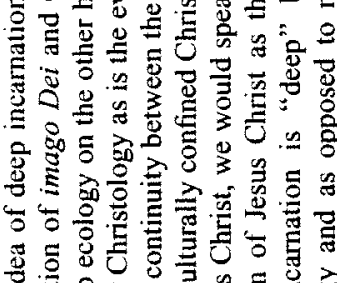

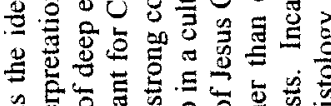

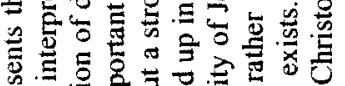

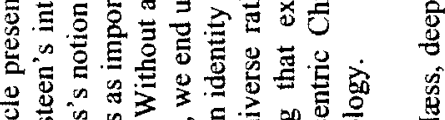

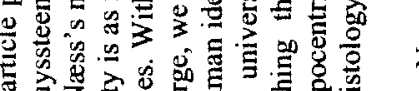

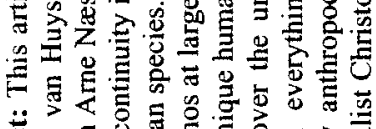

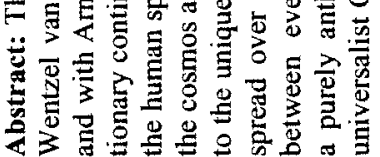

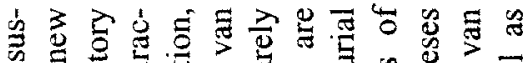

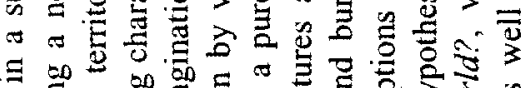

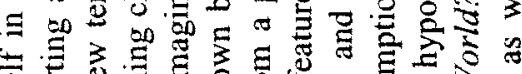

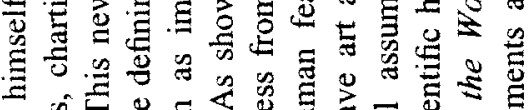

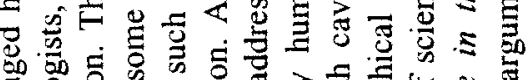

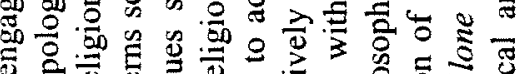

$\vec{x}$ 일

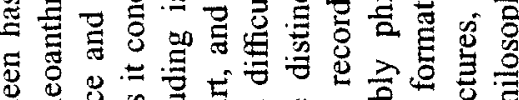

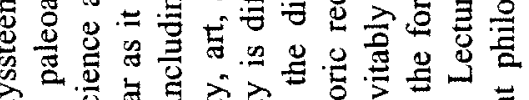

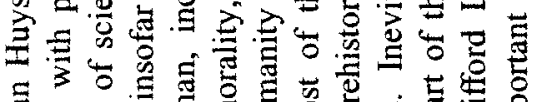

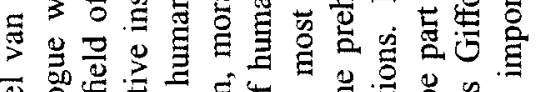

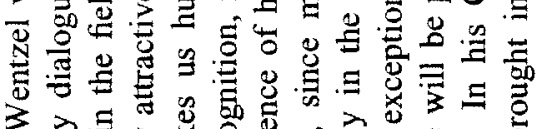

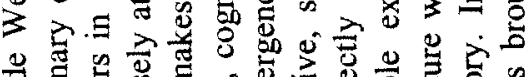

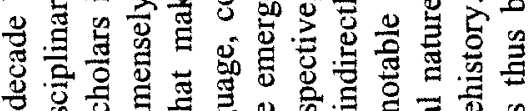

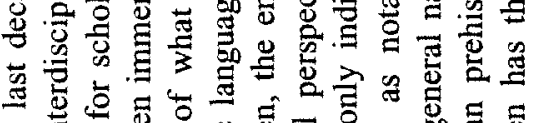

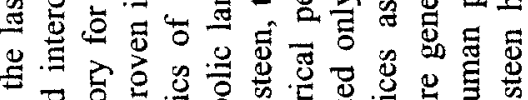

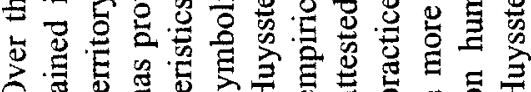

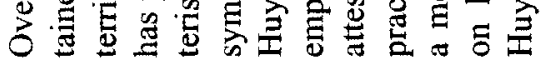

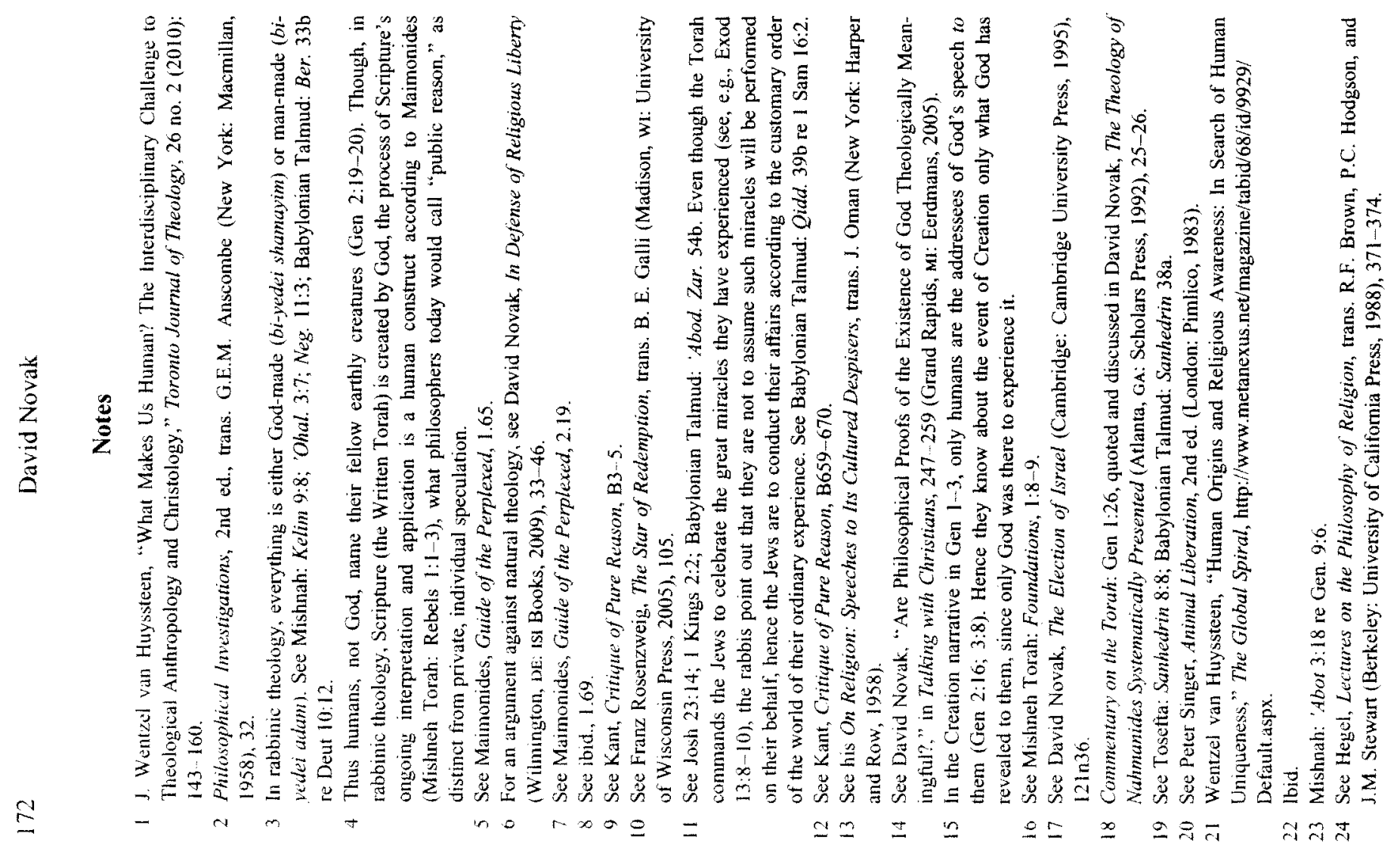




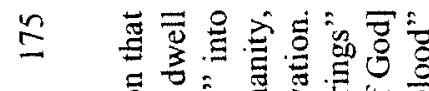

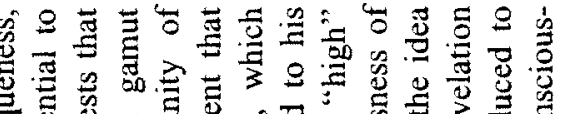

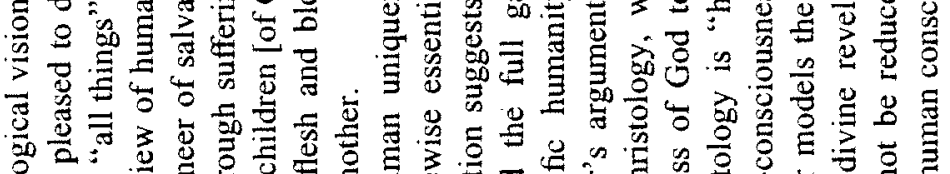

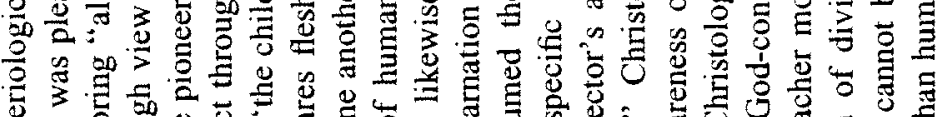

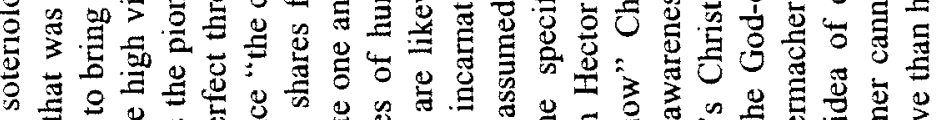

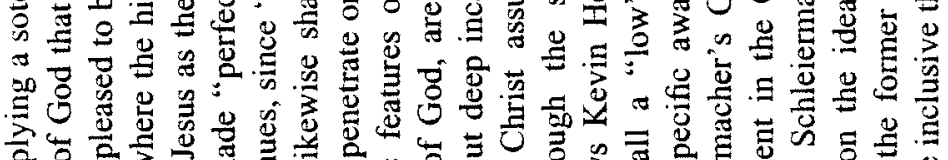

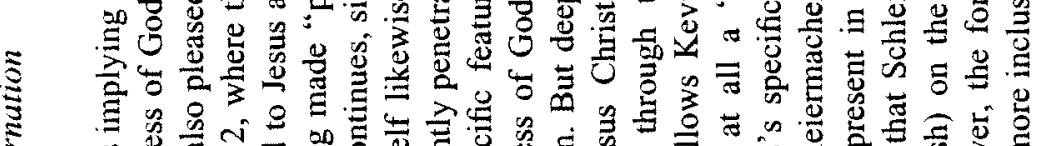

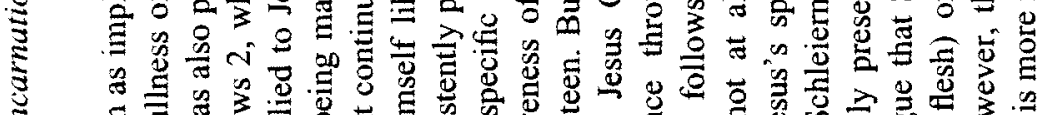
5

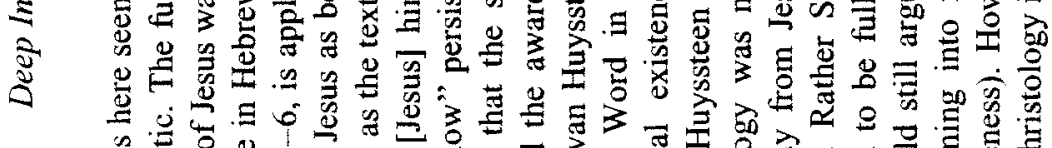

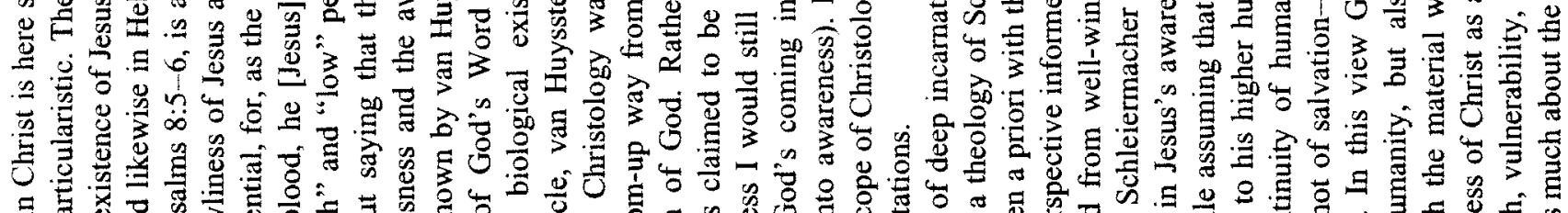

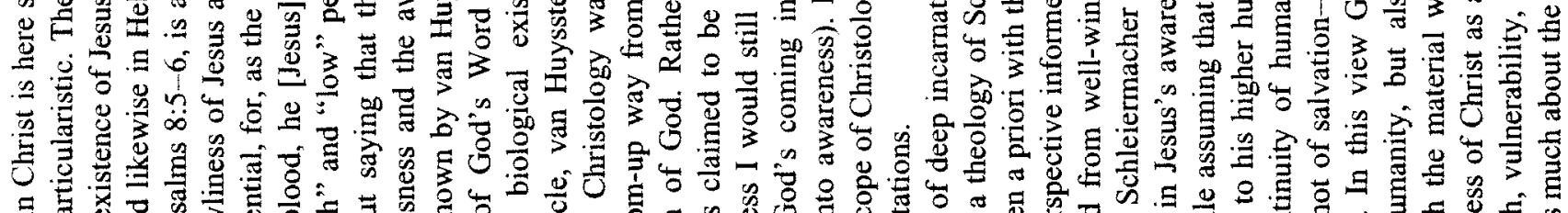

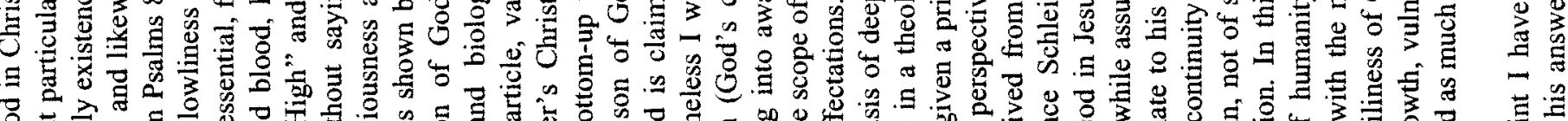

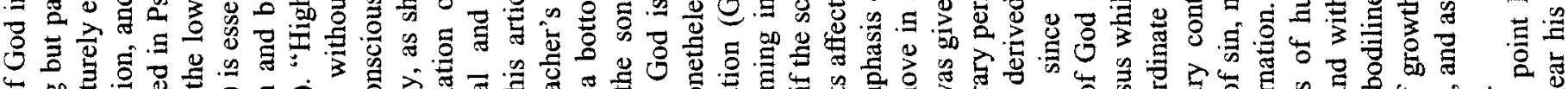

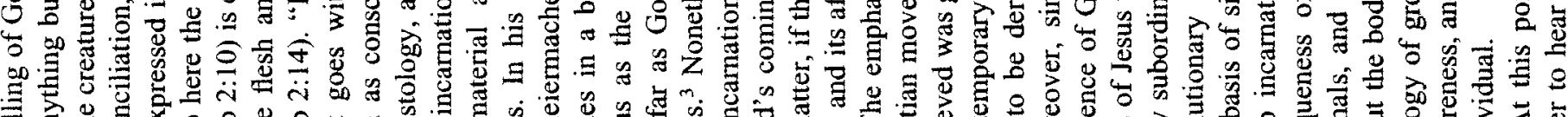

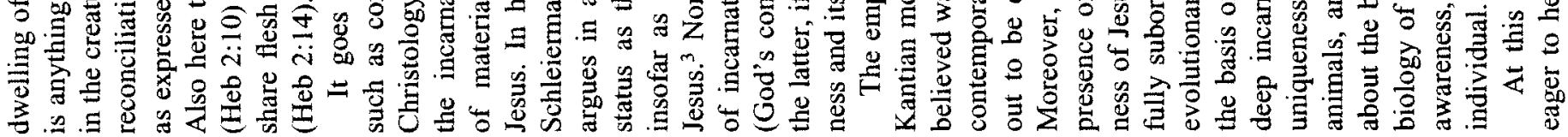

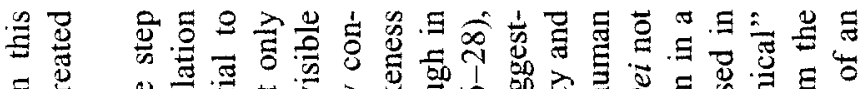

든

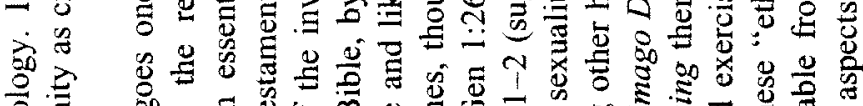

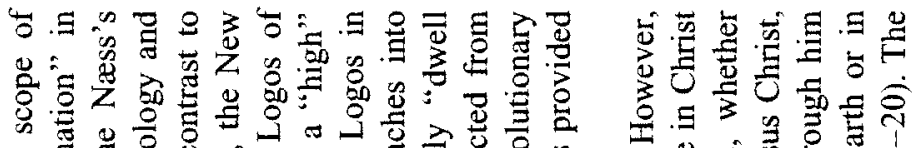
-

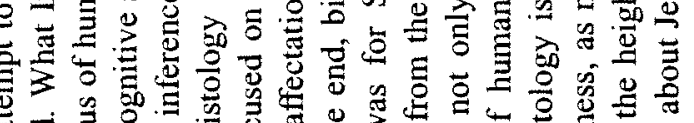

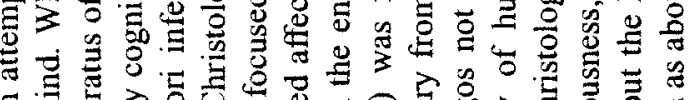

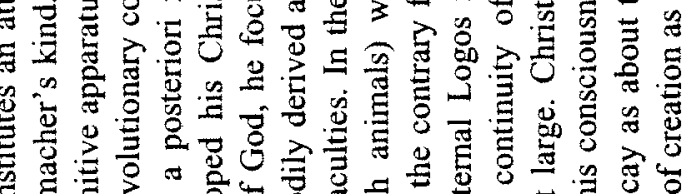

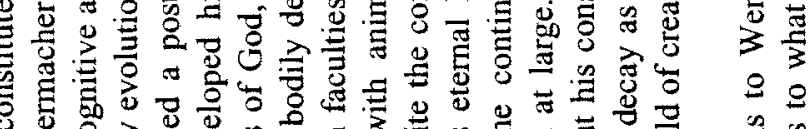

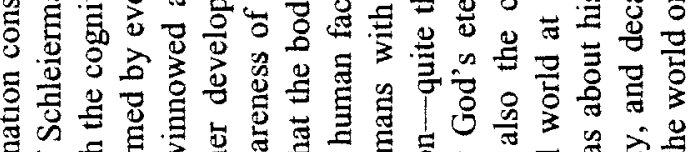

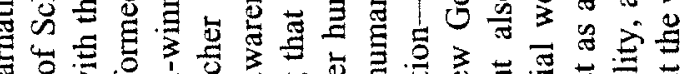
$\stackrel{2}{\stackrel{2}{2}}$ F 3 $\frac{1}{2}$

을 the

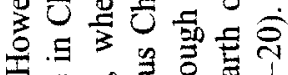

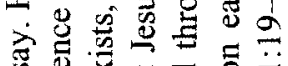
范密

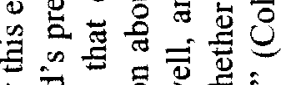

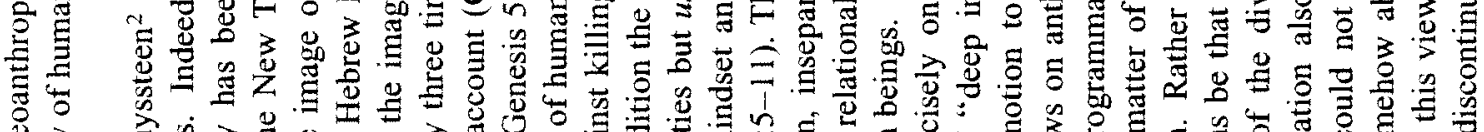

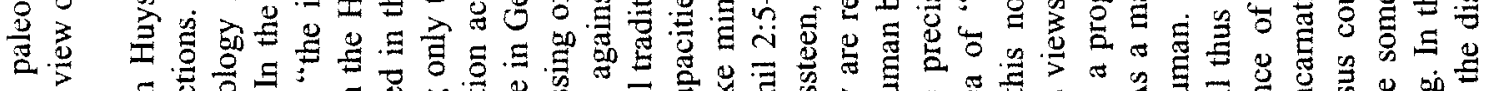

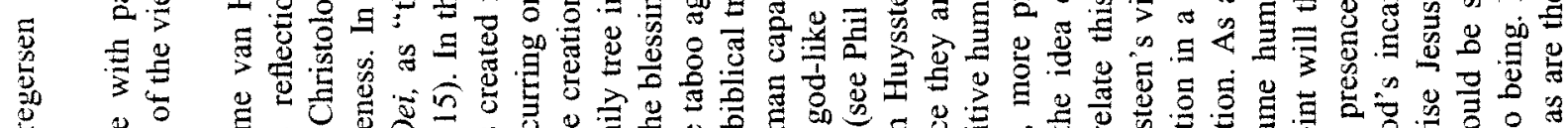

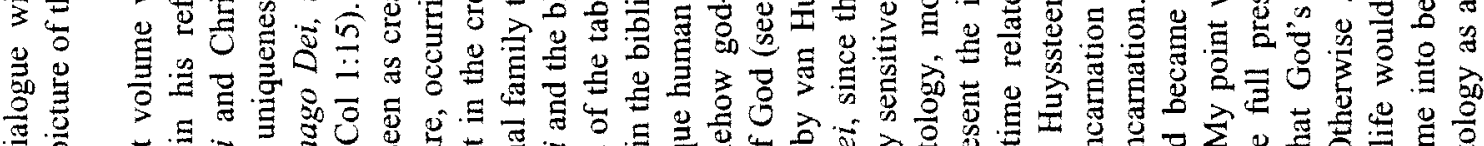

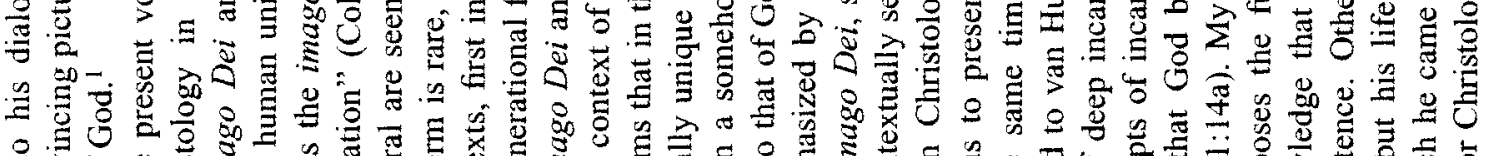

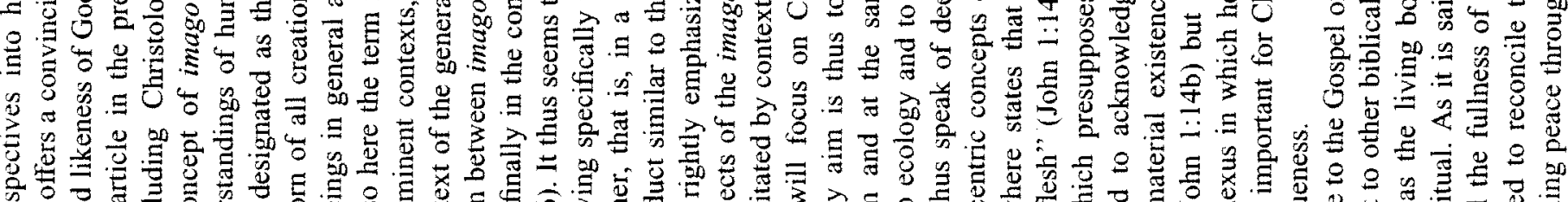

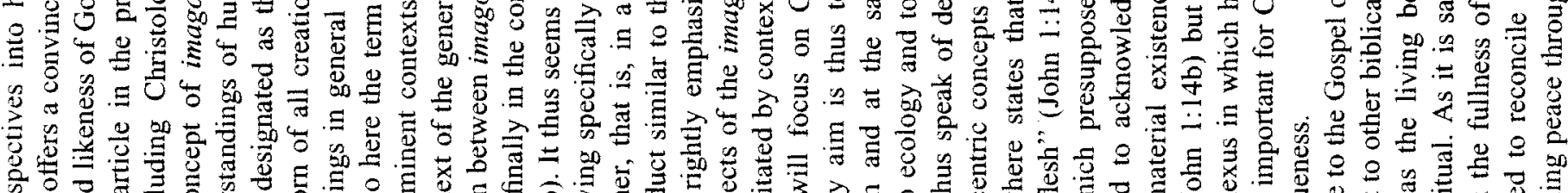

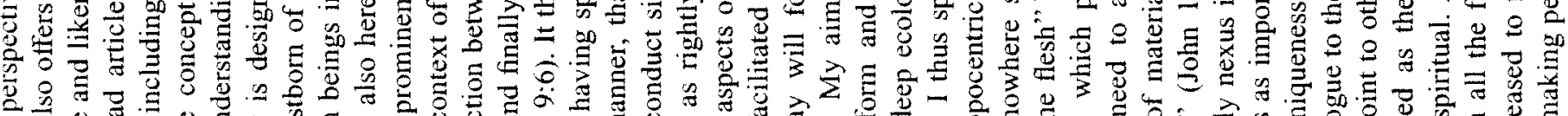
品

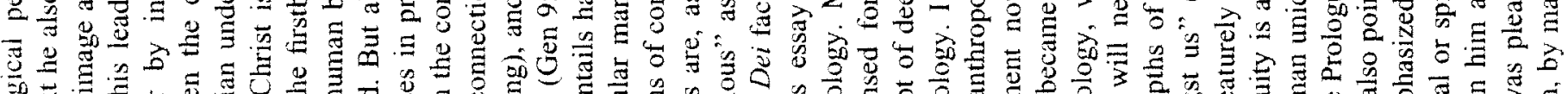

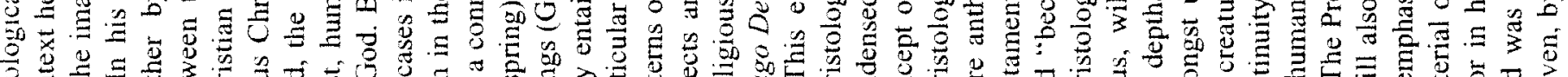

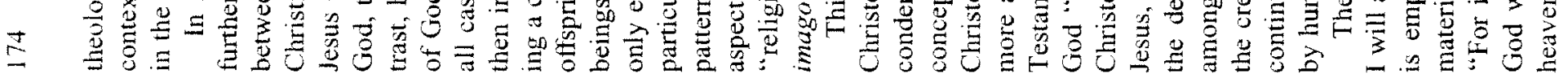




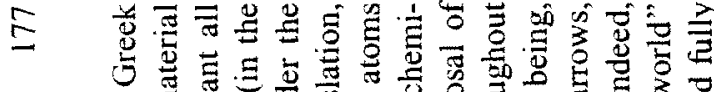

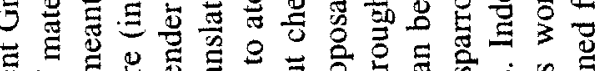

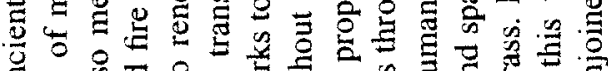

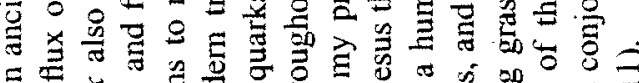
三

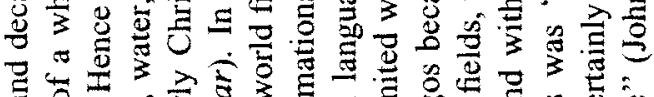

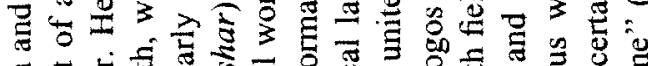

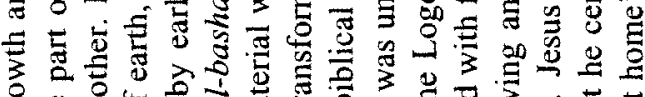

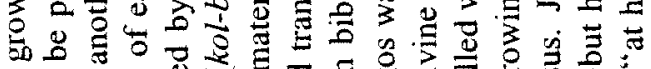

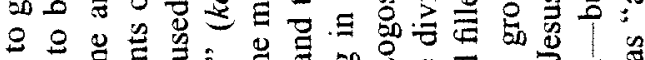

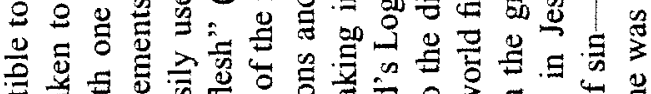
落

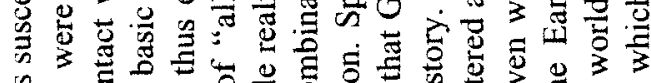

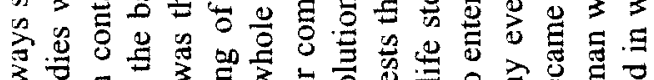

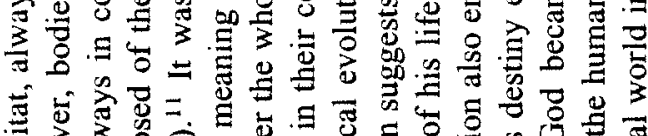

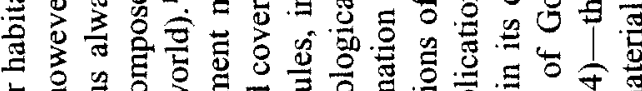

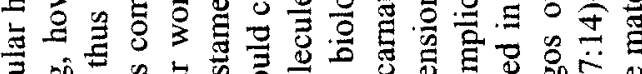

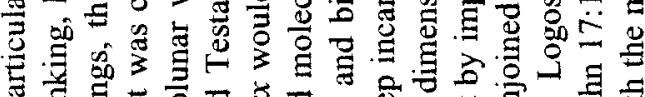

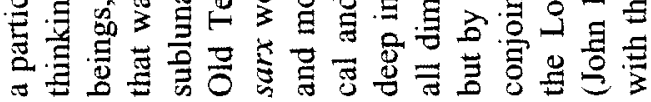

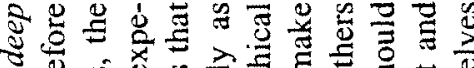

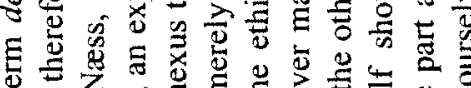

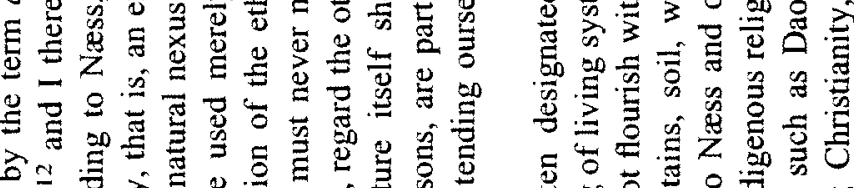

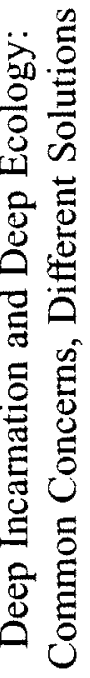
की

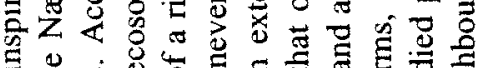

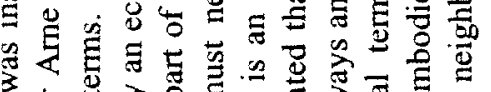

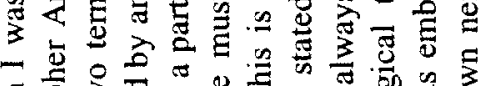

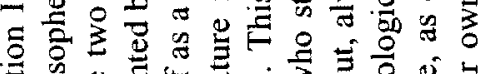

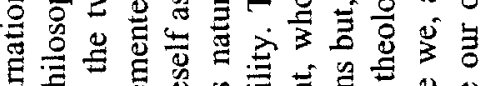

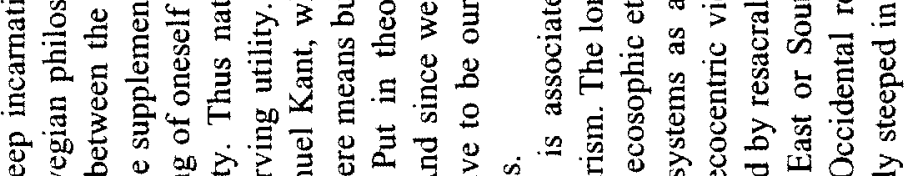

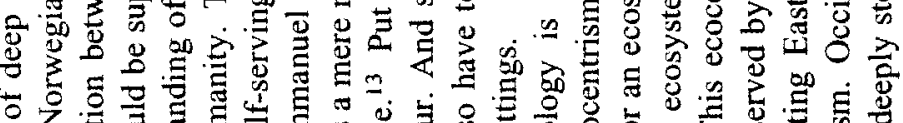

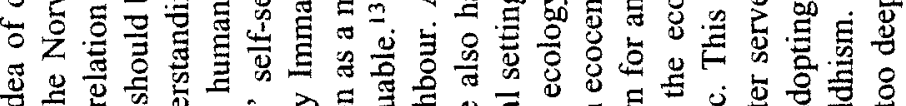

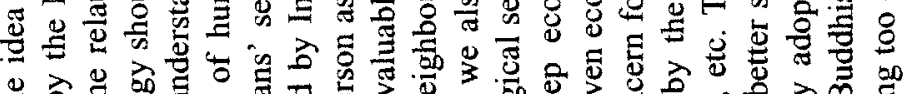

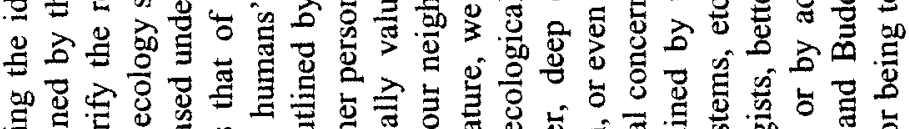

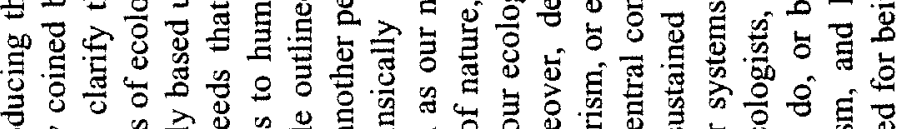

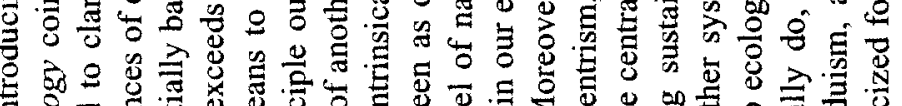

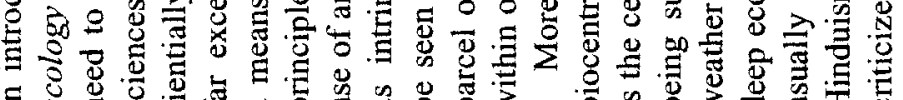

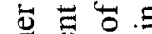

可 竞

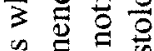

要焉

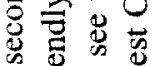

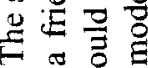

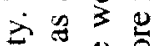

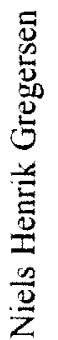

可导 过

둥

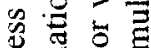

施 5

可苯

눰

4 蛋

要

送

焉跣

$\rightarrow$ 药

응옥 氛

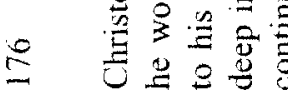

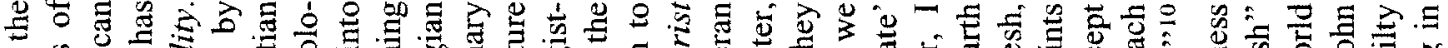

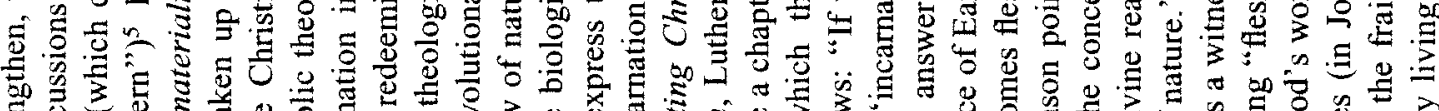

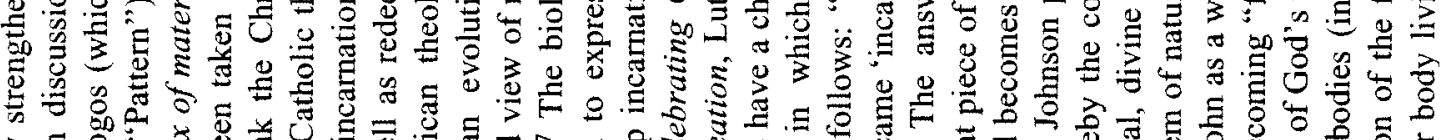
2.

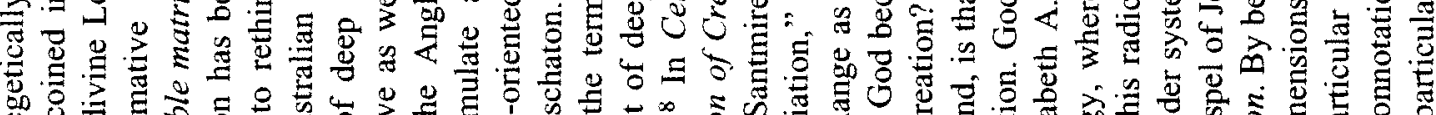

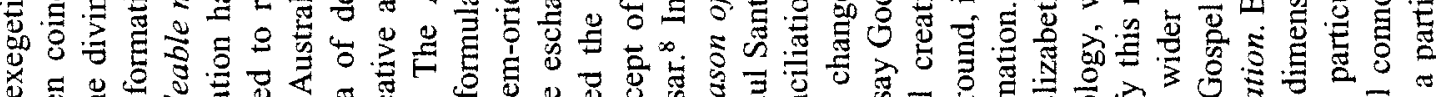

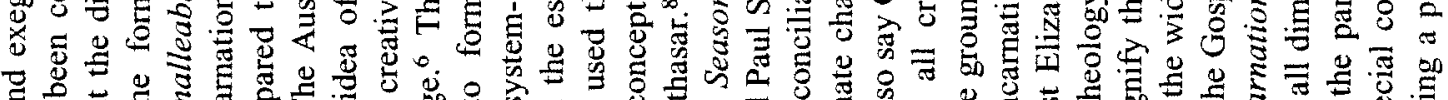

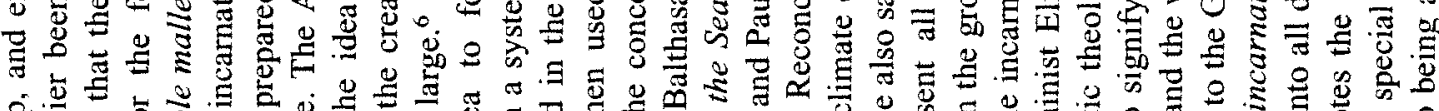

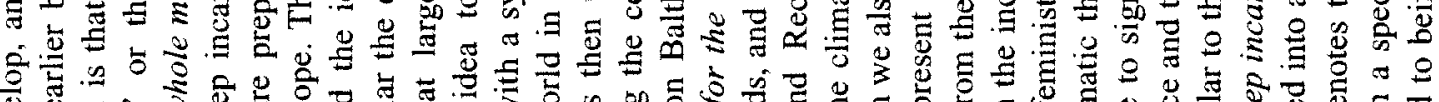

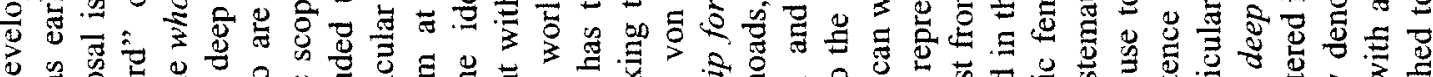

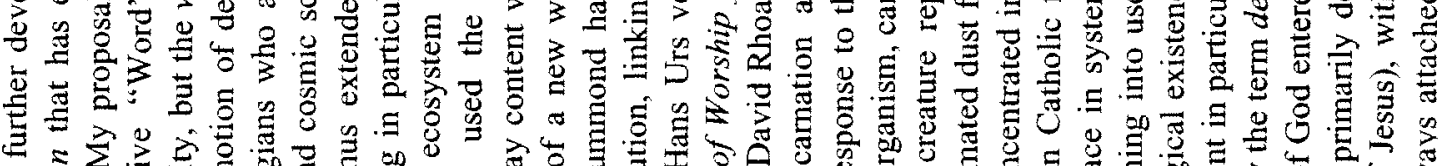

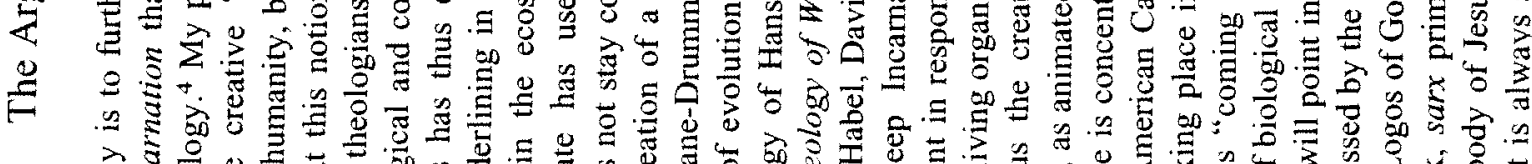

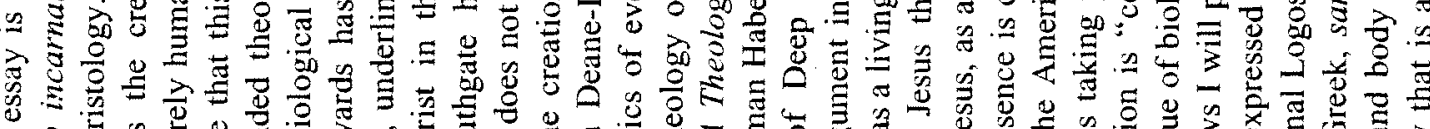

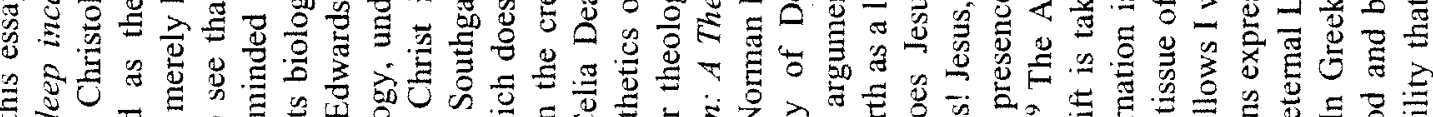
E

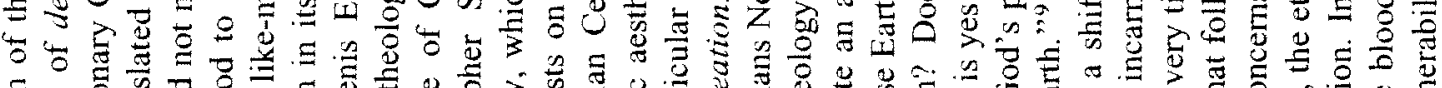

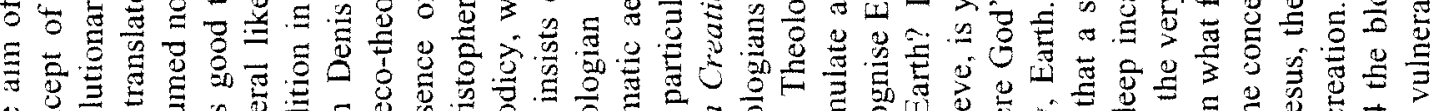

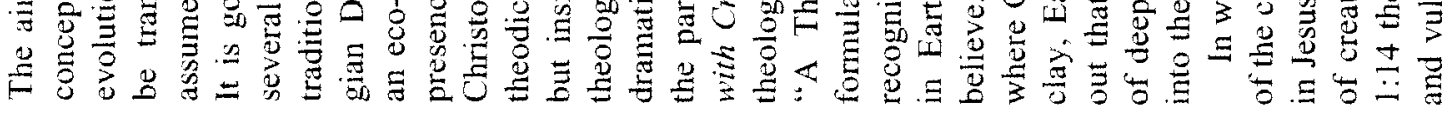




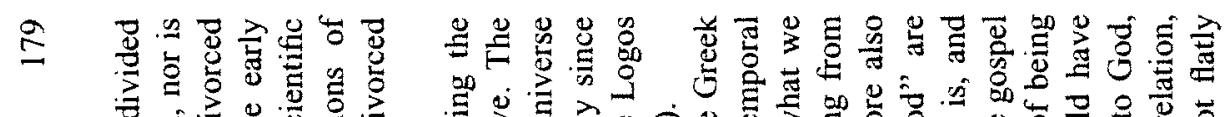

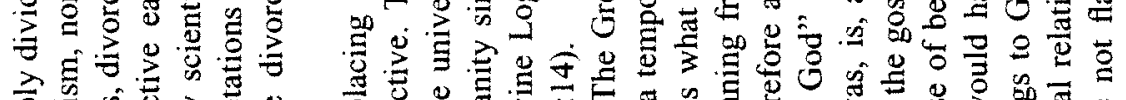

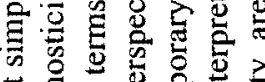

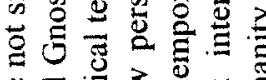

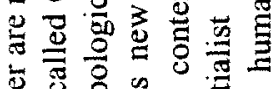

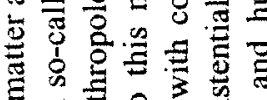

5

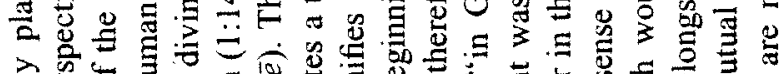

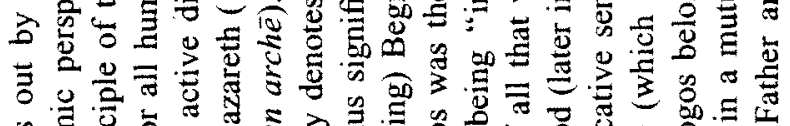

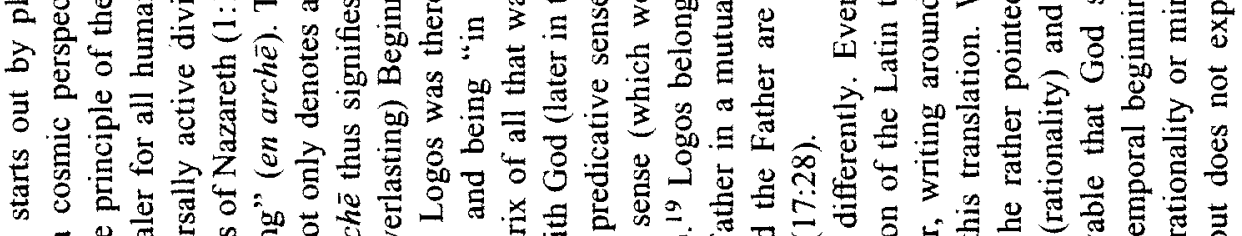

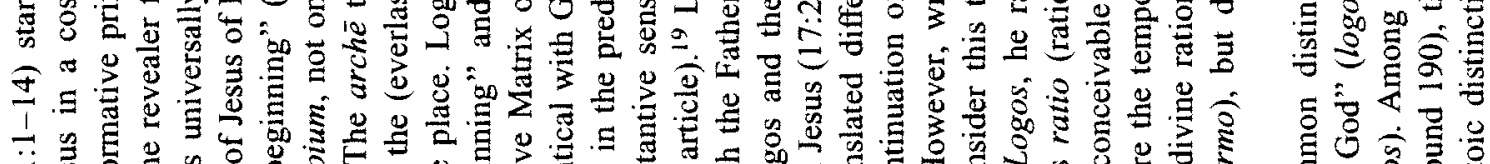

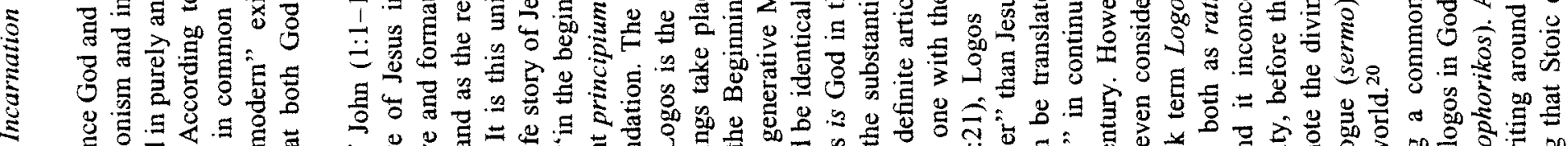
艺

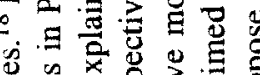

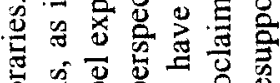

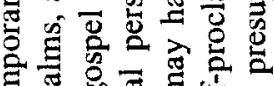

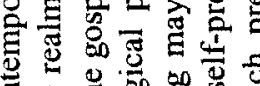

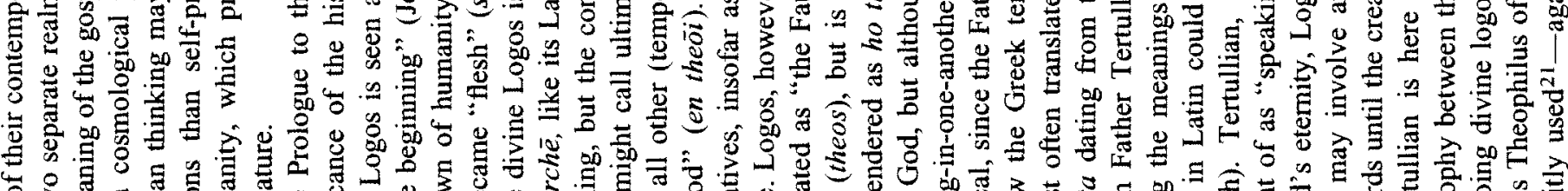

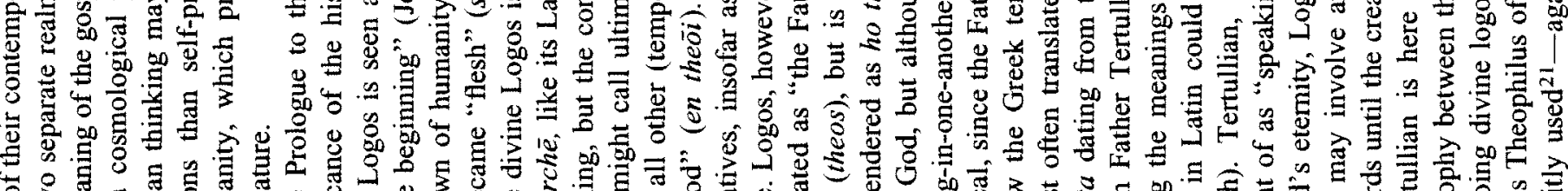

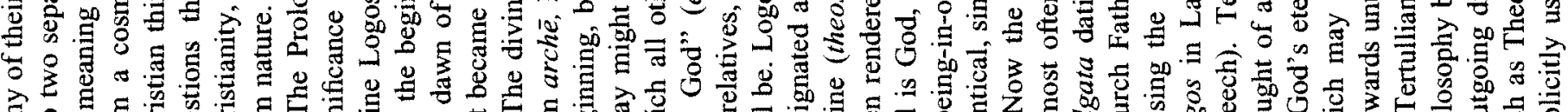

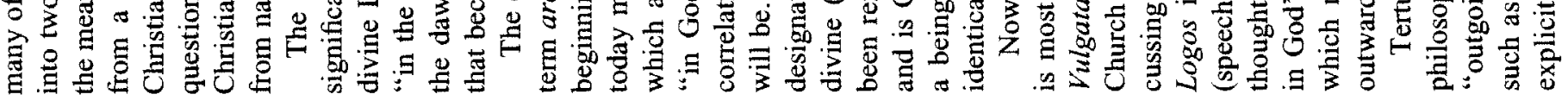

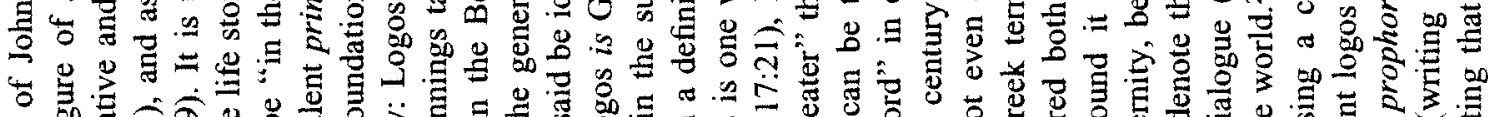

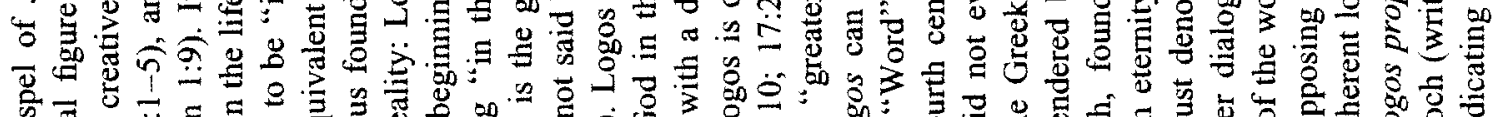

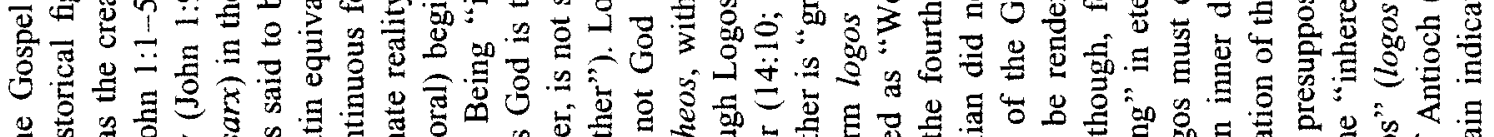

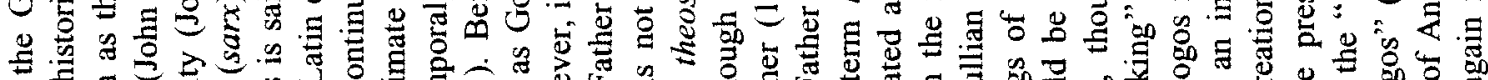

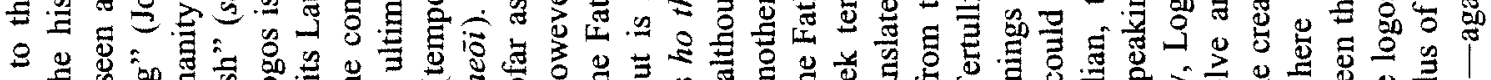

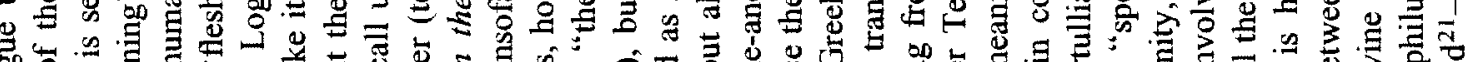

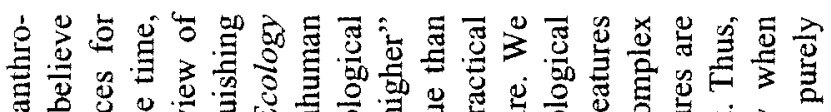

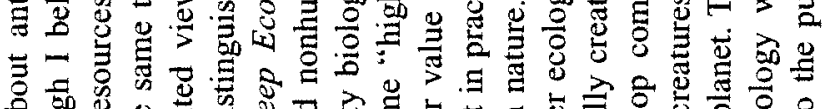

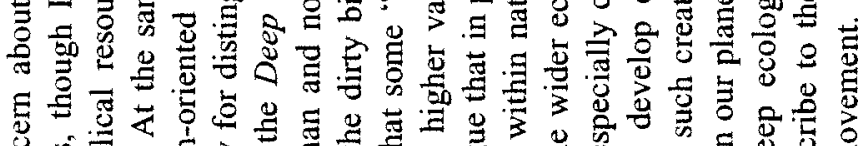

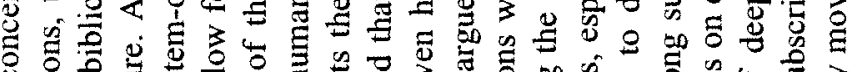

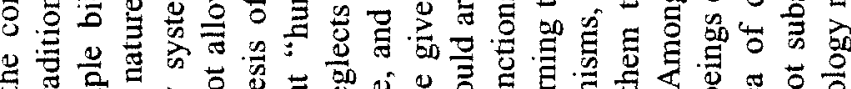

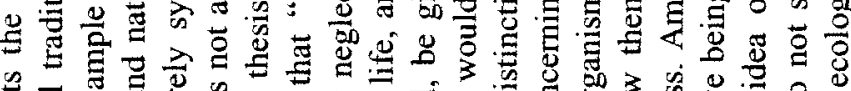

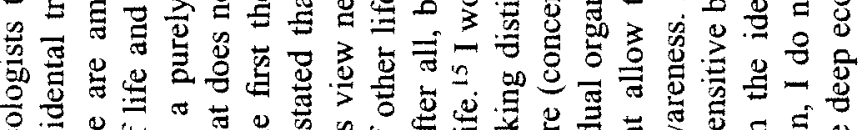

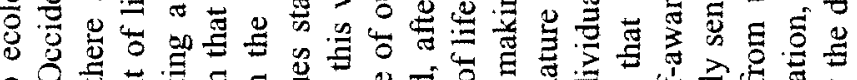

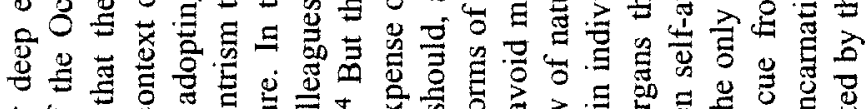

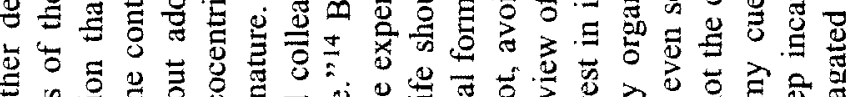

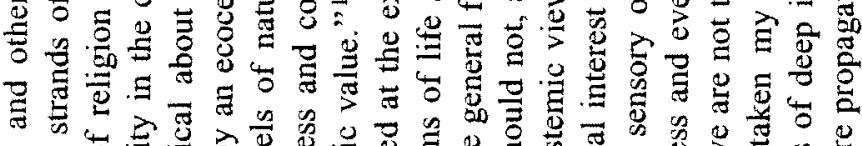

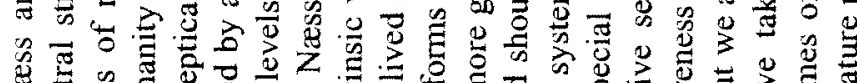

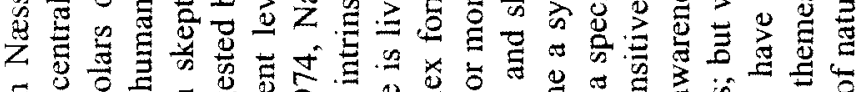

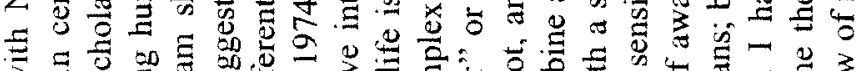

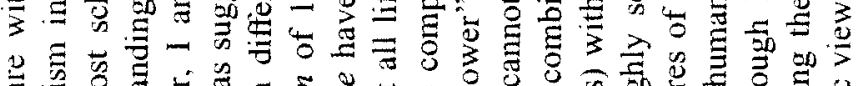

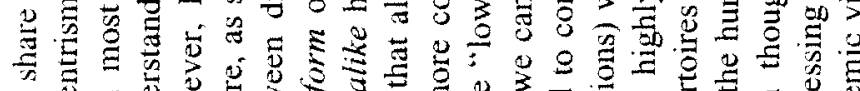

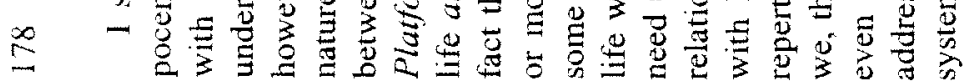

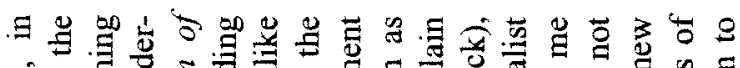

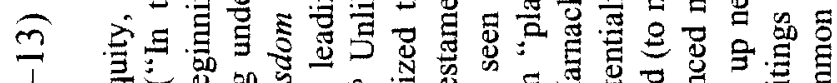
․

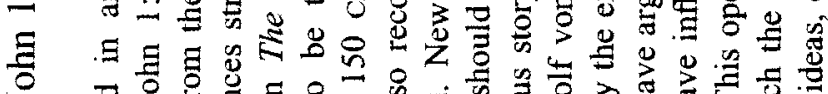

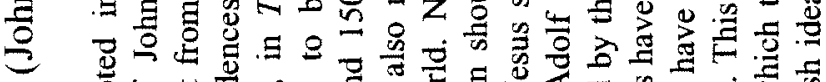

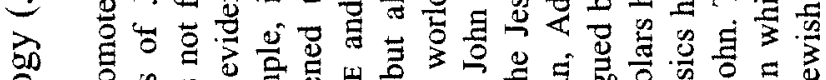

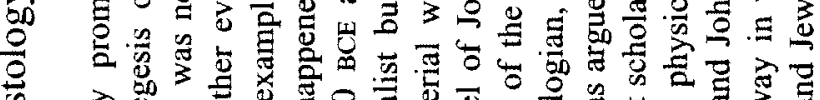

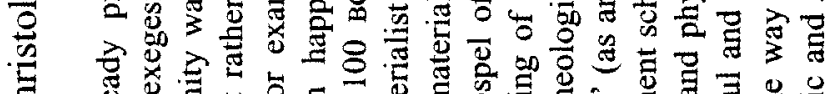

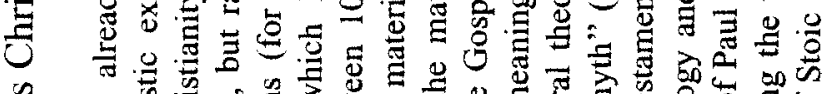

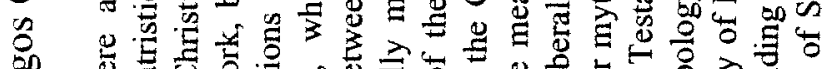

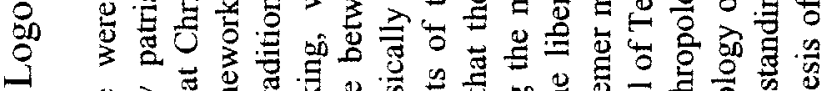

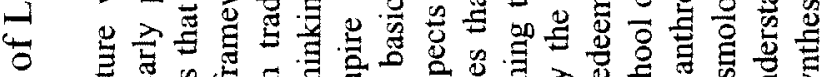

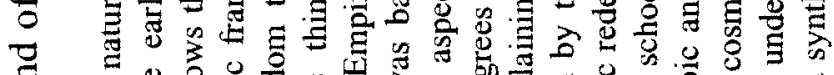

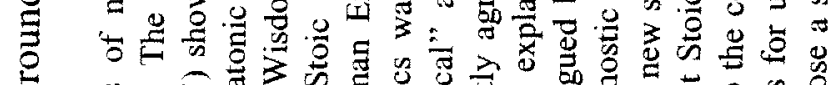

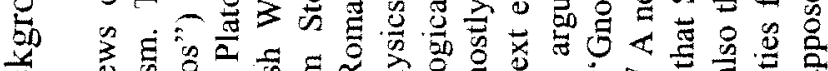

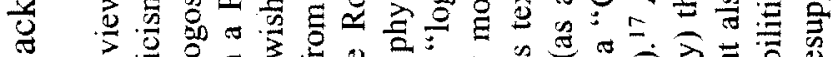

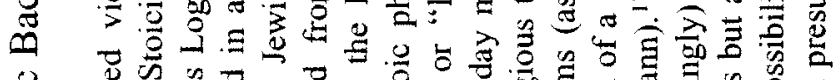

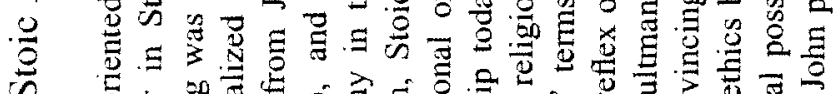
只

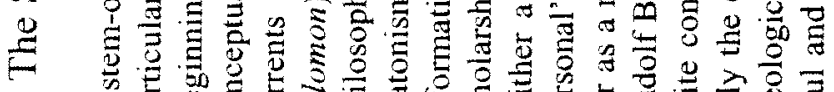

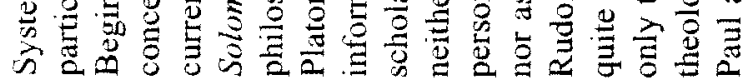




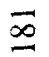

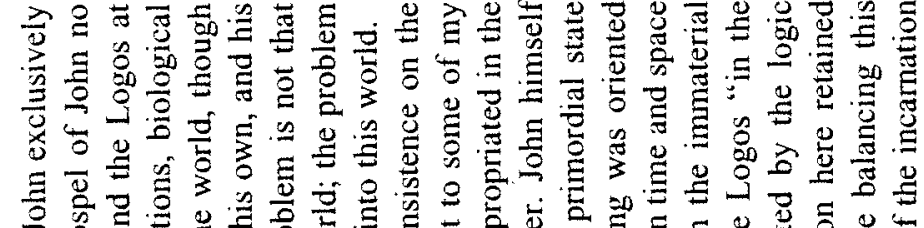
응

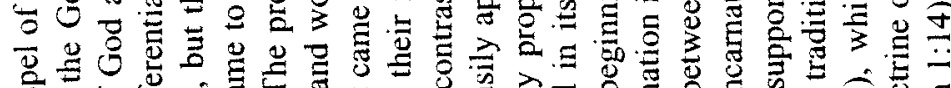

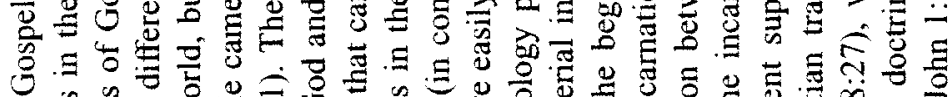

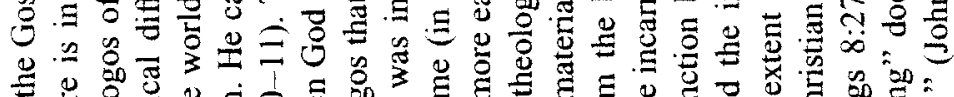

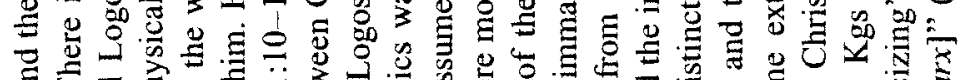

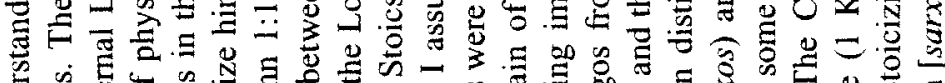

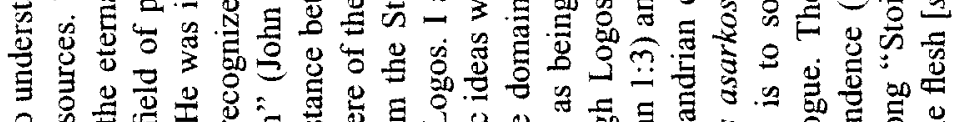
ミ

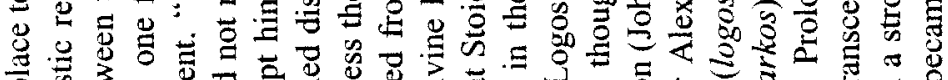

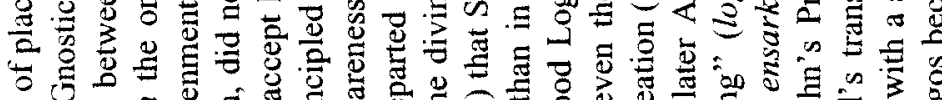

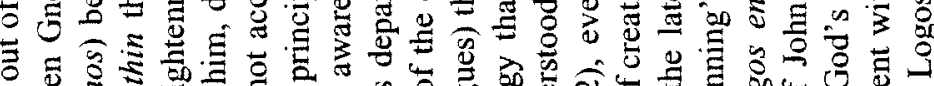

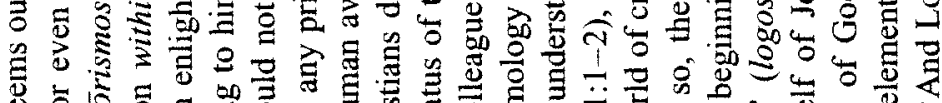

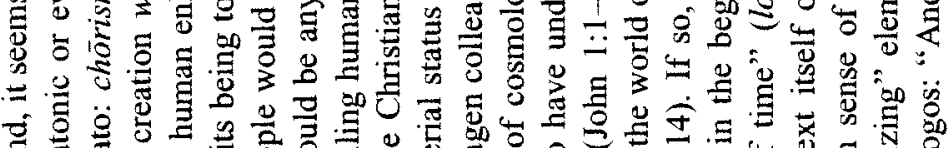

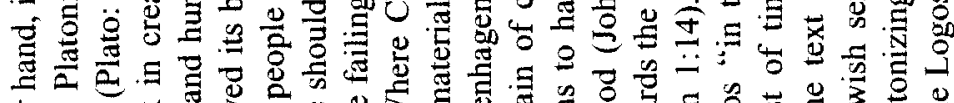

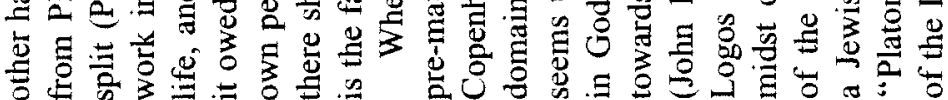

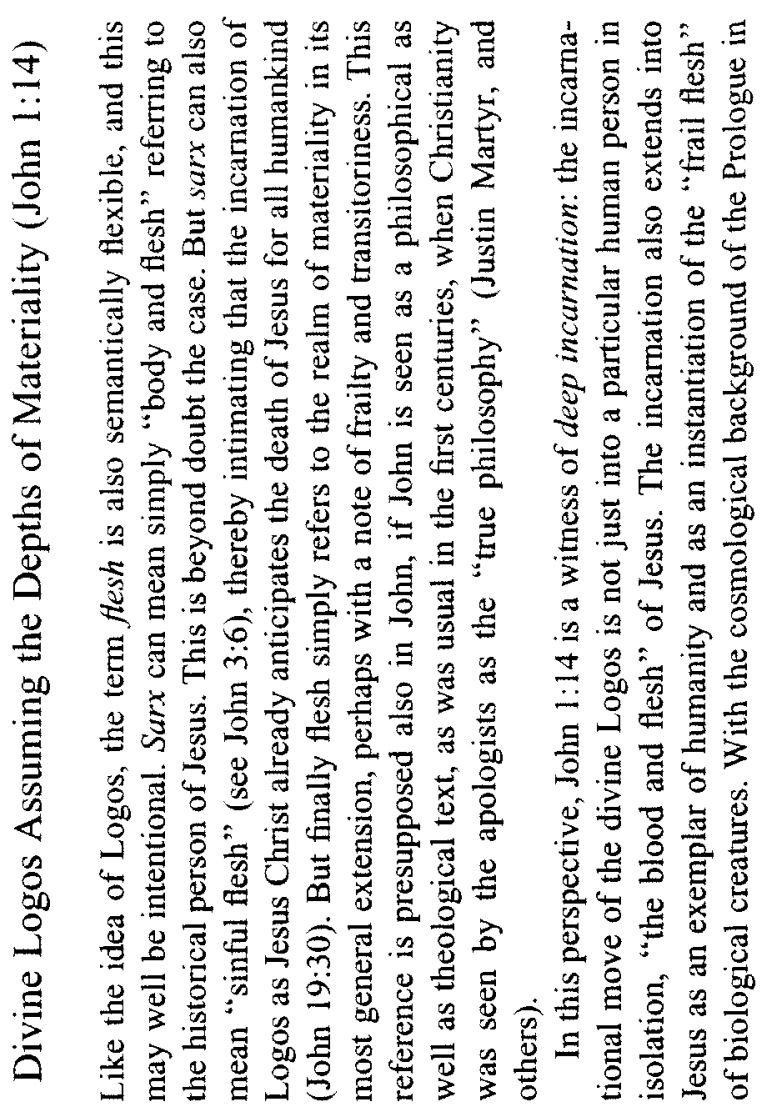

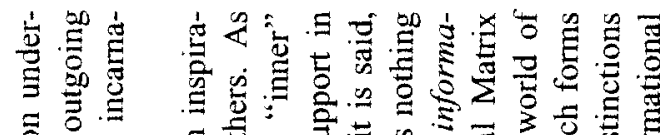

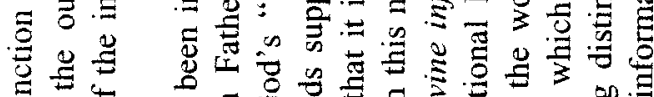

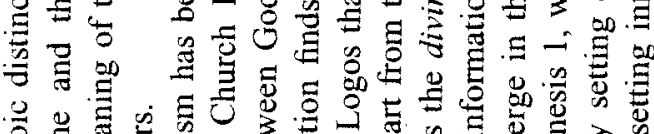

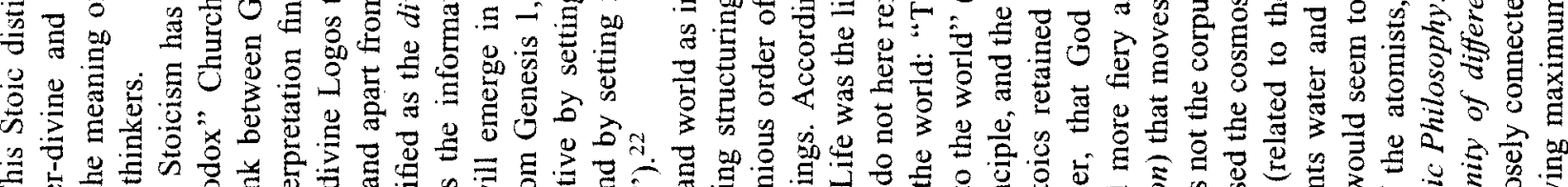

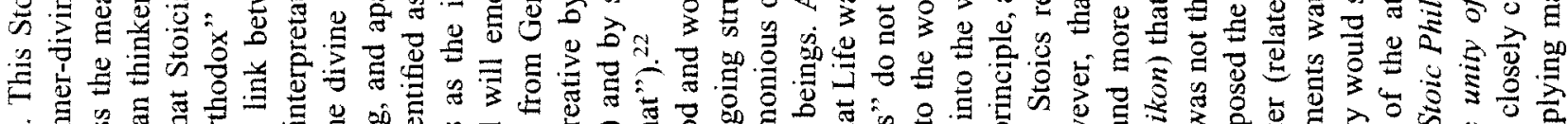

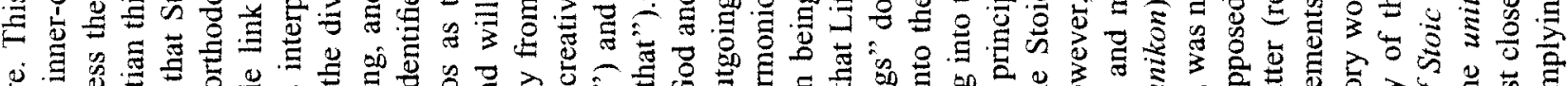

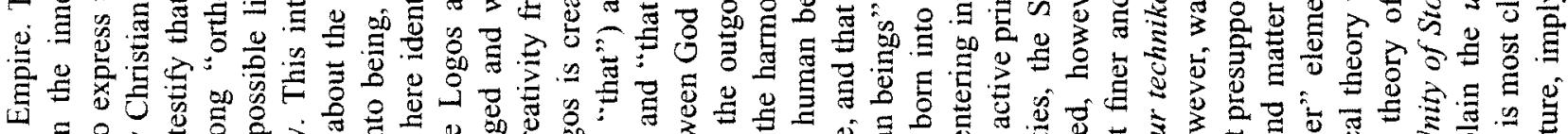

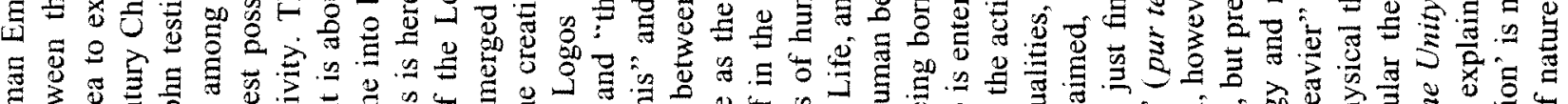

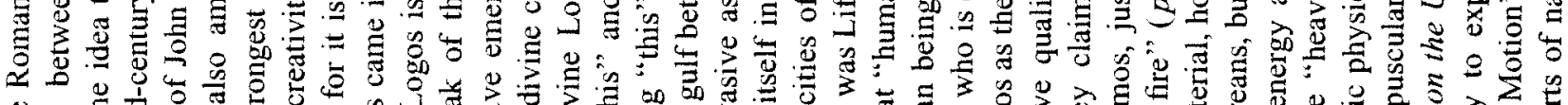

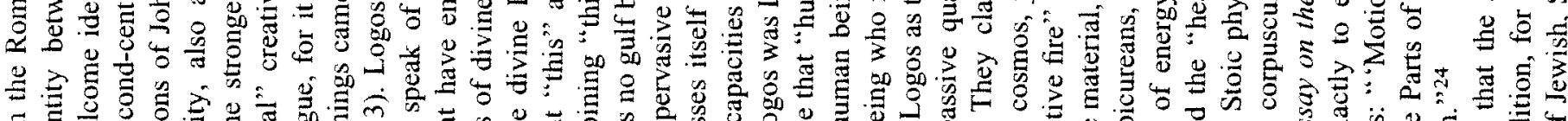

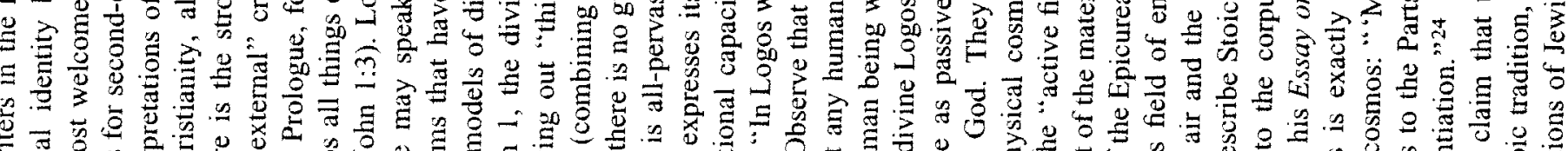

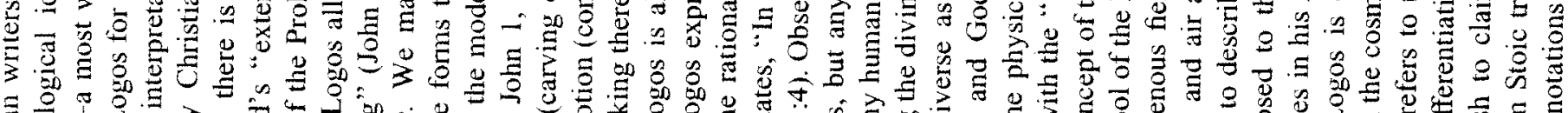

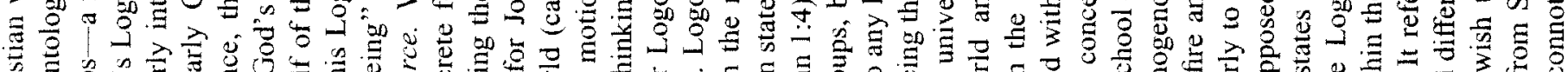

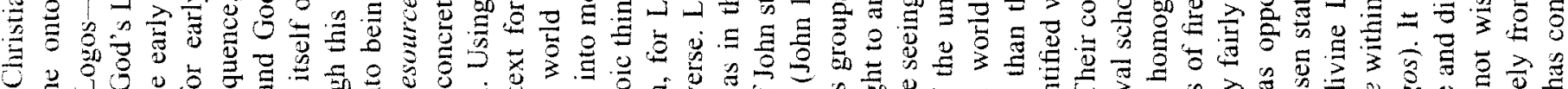

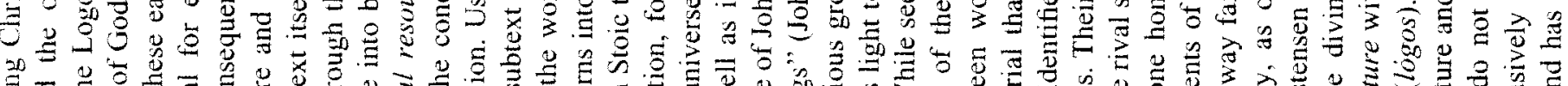

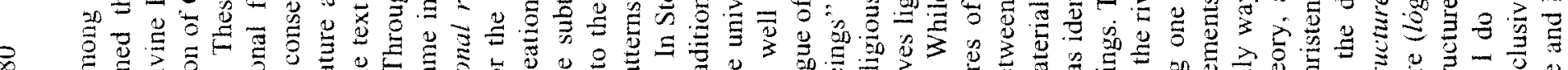

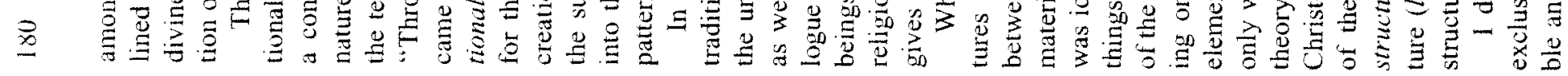




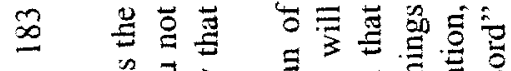

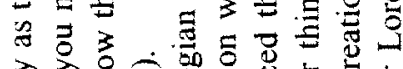

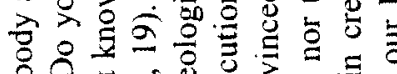

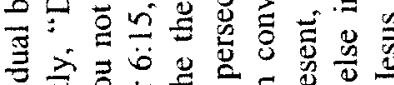

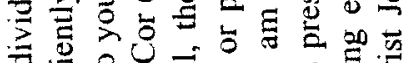

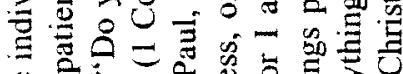

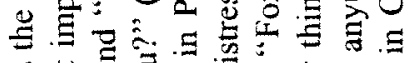

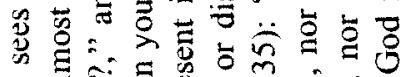

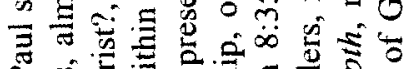

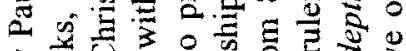

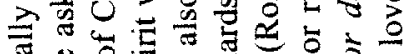

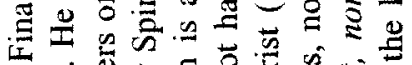
ฐ

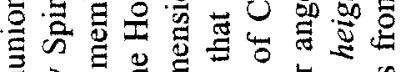

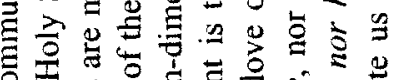

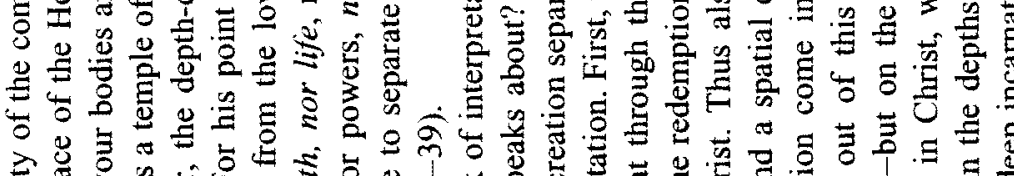

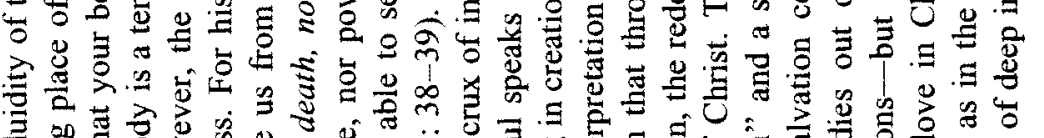

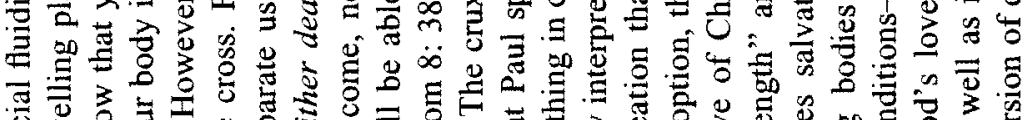

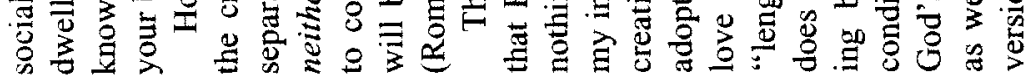

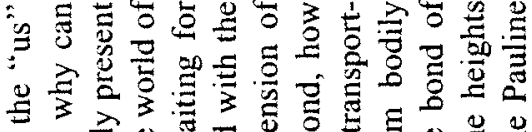

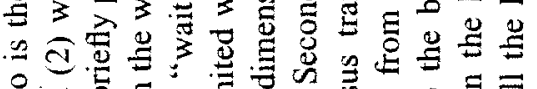

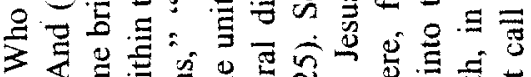

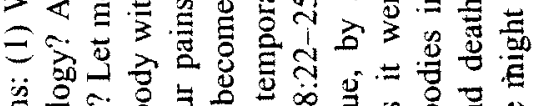

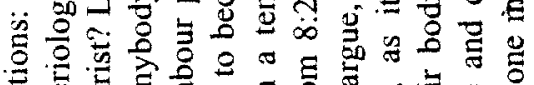

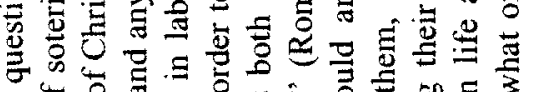

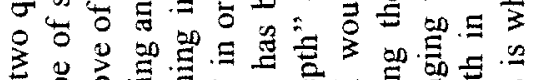

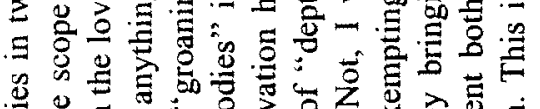

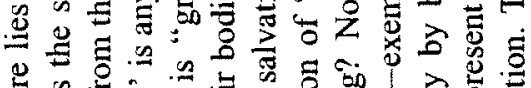

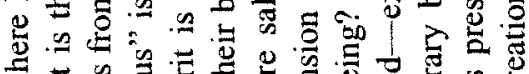

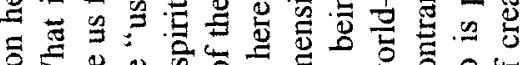

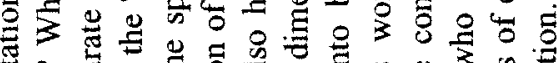

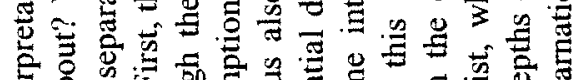

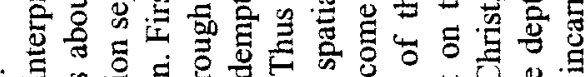




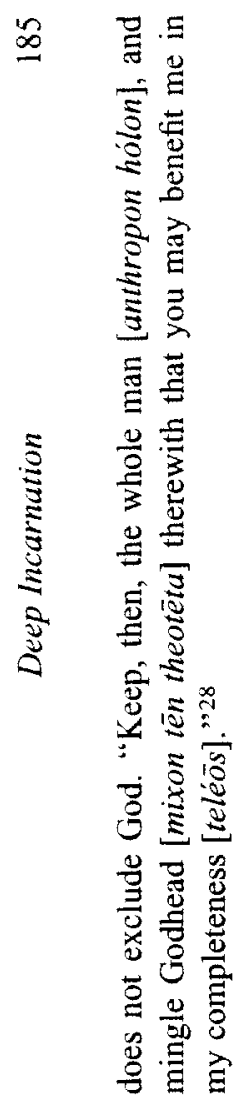

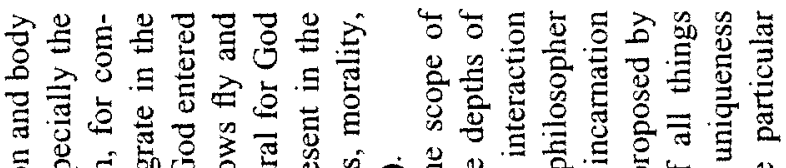

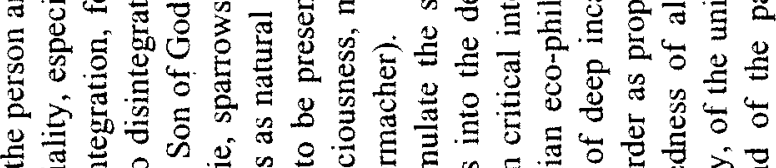

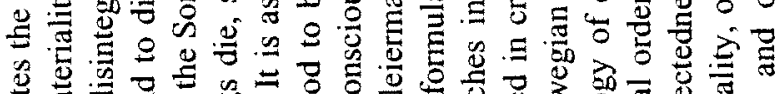

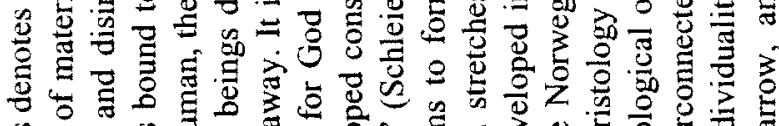

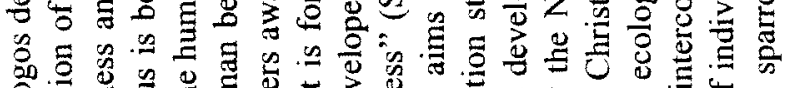

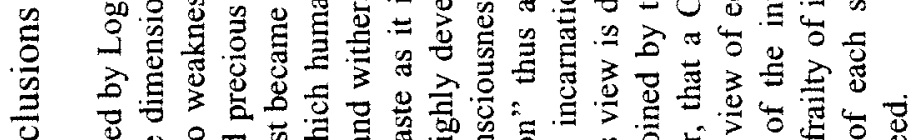

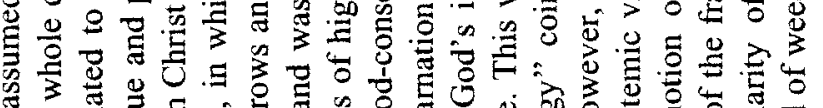

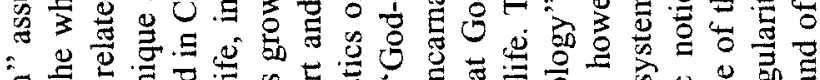

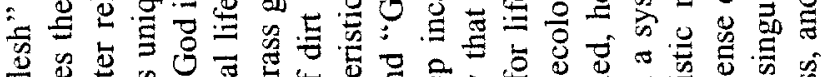

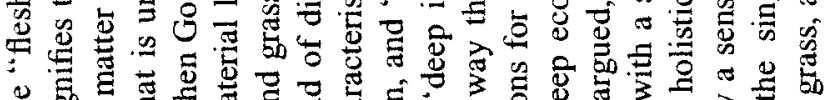

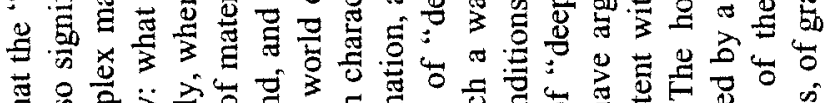

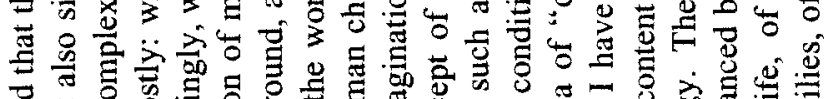

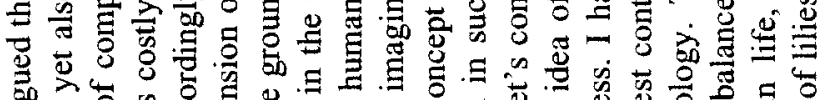
空

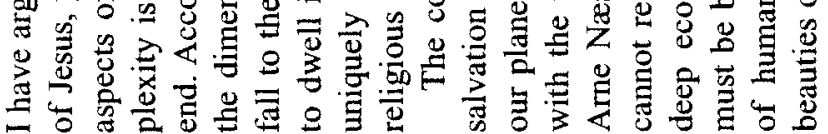

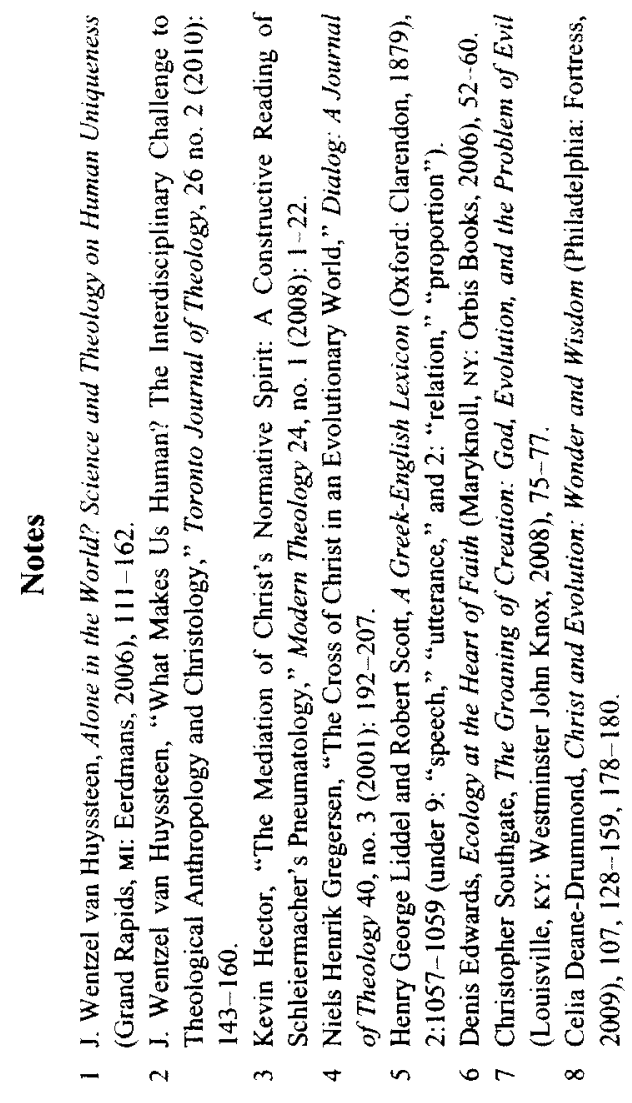

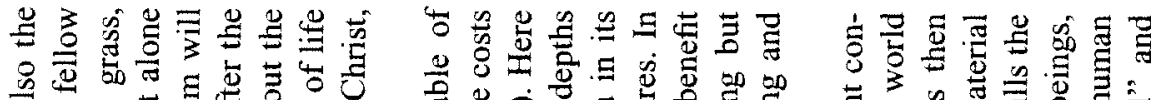

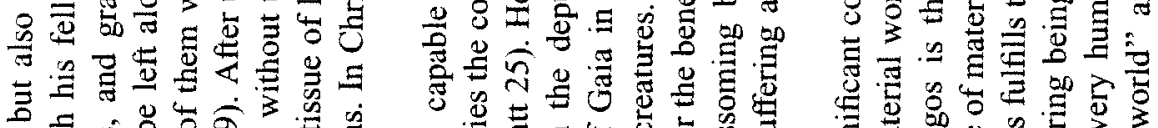

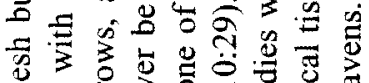
有

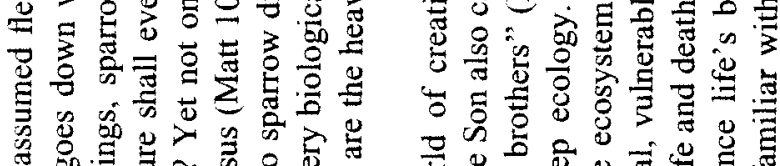

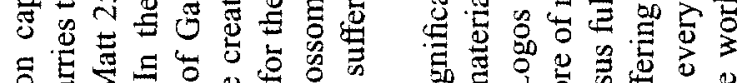

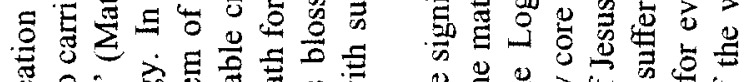

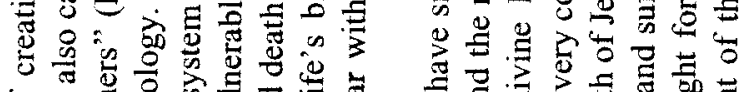

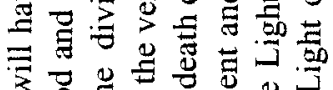

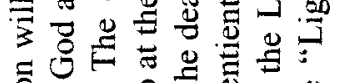

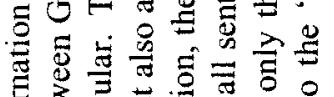

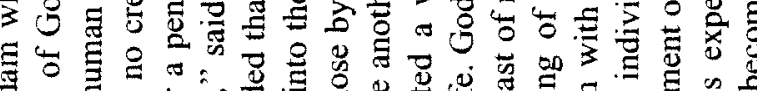

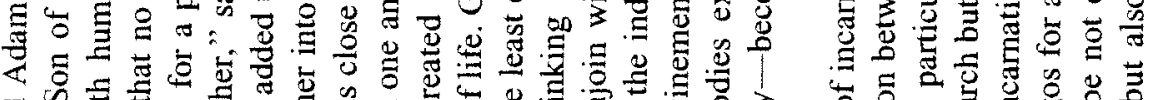

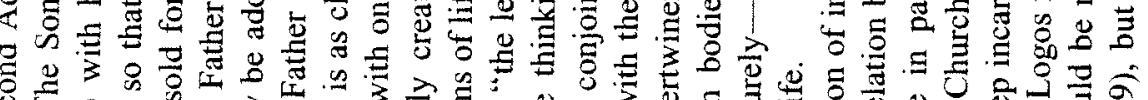

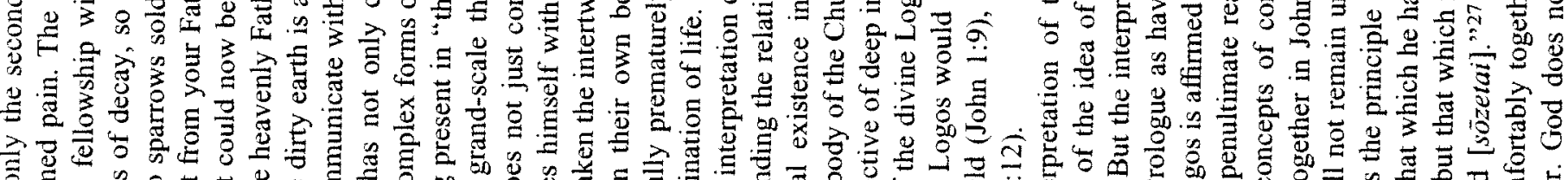

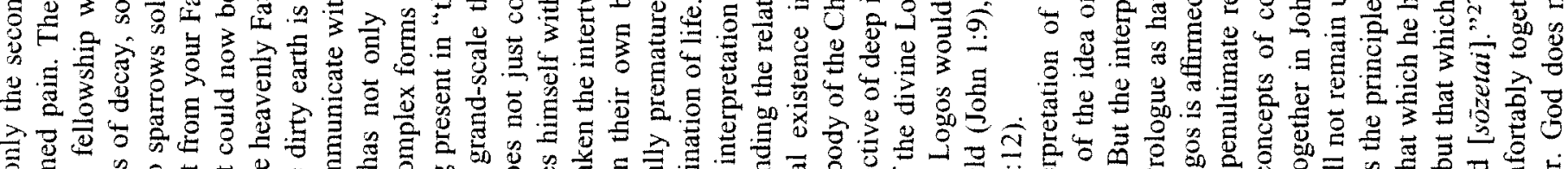

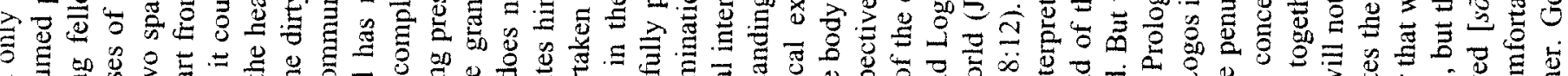

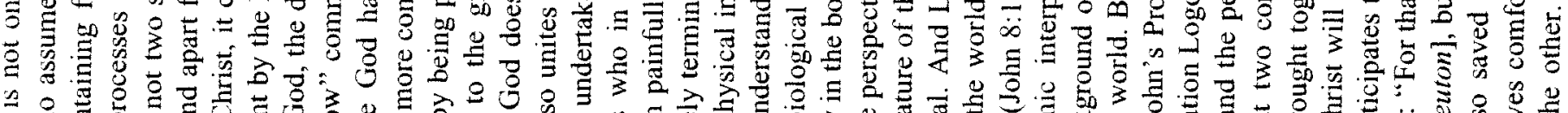

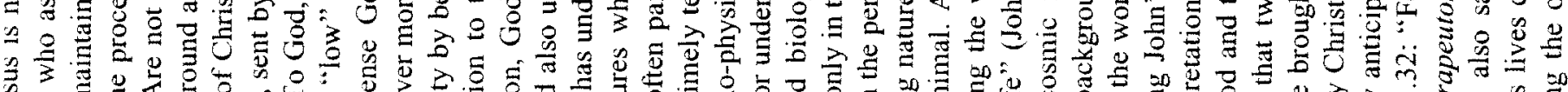

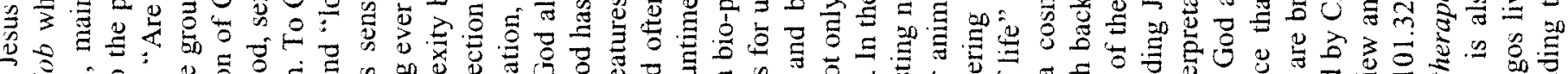

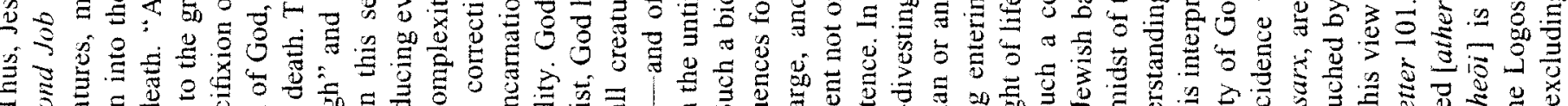
士

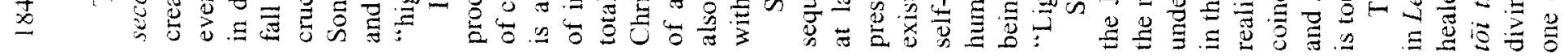



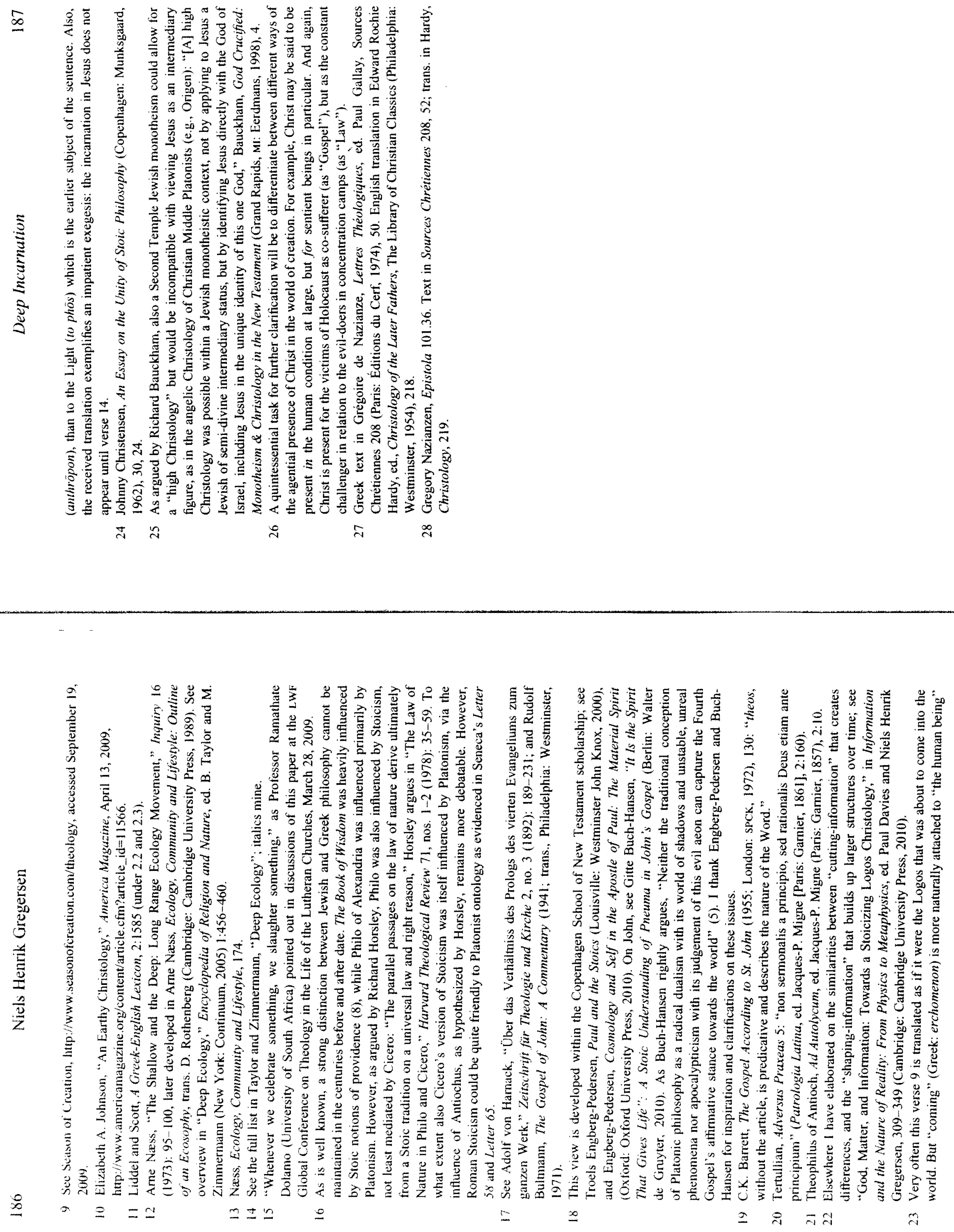